\title{
Analysing elite careers
}

\author{
Jacob Aagaard Lunding, Christoph Houman Ellersgaard, Lasse Folke Henriksen \& Anton Grau Larsen \\ Department of Organization, Copenhagen Business School. Correspondence: che.ioa@,cbs.dke
}

\begin{abstract}
:
In this paper, we propose a methodological framework to analyse cross-sectorial elite career using sequence analysis to identify particular career trajectories. As empirical case, we use 416 members of the Danish power elite, found in the core of the Danish elite networks. We describe how career data can be constructed based on CV's, how career states can be coded and how sequence analysis in combination with optimal matching and of hierarchical agglomerative clustering can be used to develop typologies of careers.
\end{abstract}




\section{Introduction}

The purposes of this paper is to provide a methodological framework for building a typology of career patterns. Thus, we describe how sequential data of careers can be collected and coded for cross-sectorial elites and how to use optimal matching distances between individuals to create a set of different career clusters or trajectories. Finally, we describe how to compare these clusters based on their different characteristics.

Since any comparison will always rest on the selections and definitions of the different qualities and characteristics on which the compared may differ or not, the main focus of this working paper is laying out the principles behind our approach.

Our population is what we call the Danish power elite: 423 individuals belonging to the core of the Danish elite networks in 2012. These were identified though a k-core decomposition to a large relational database of 5079 boards, networks, committees and councils consisting of 37,750 individuals and 56,536 positions (a more detailed description of the methodology is described in Larsen \& Ellersgaard 2017).

To analyse their careers we draw upon sequence analysis. Sequence analysis has already been used to study elite careers (Abbott \& Hrycak, 1990; Araujo 2018; Blair-Loy, 1999; Bühlmann, 2008; Koch, Forgues, \& Monties 2017; Ohmura, Bailer, Meißner, \& Selb 2018; Stovel, Savage, \& Bearman, 1996; Seabrooke and Nilsson 2015). However, all these studies focus on elites within a particular sector. The framework developed here aim to extend this work to be used for a cross-sectorial elite group.

\section{Data: Constructing the curriculum vitae data of the power elite}

We draw on a wide range of sources. Portraits from the Danish equivalent of Who's Who, Kraks Bla Bog, were supported by LinkedIn profiles and official CVs found online. Further information is drawn from approximately 3,000 newspaper portrait articles, acquired from infomedia.dk, a Danish newspaper article database. Records were made on a year-to-year basis of the name and location of the employer organization and descriptions of the job function. Furthermore, we gathered information on biographical details such as social background, level and type of education and age from the same sources. Finally, we use the network centrality calculated in Larsen \& Ellersgaard (2017) to compare the groups identified in the analysis.

Some issues with the collection and treatment of CV are worth mentioning here. And many of these issues concern the status of an employment. First, the time span can be difficult to access. Periods of employment may not always be recordable in full length years. We dealt with this by simply rounding up to one year, when the 'event' was more than half a year. Second, a time span in a CV or a portrait might cover several employments, e.g. in 1982 to $2005 \mathrm{X}$ was employed in A, B and C. In such cases, each employment was given a proportional share of the whole period. Third, with regard to geographical location and career level, in particular, the actual rhythm of ascend or the circulation between different offices may be 'invisible' in a CV that only mentions the final position. In case this could not be reconstructed from other sources, we had to go 
with the reported place and career level, even if it seemed somewhat implausible. One example could be a CEO, who reports 15 years of employment as a 'director' in a medium-sized corporation directly after finishing his university degree. It would seem plausible that he had in fact moved his way up to a management position, but none of our sources can help us to distinguish the different career levels.

\section{Coding of career states}

Based on the reconstructed CVs, we constructed each career as an approximate year-by-year succession of definite sets of possible states in six channels: sector, sub-sector, organization, organizational size, career level and geographical position (see Table 1). In the analyses, we restricted ourselves to an analysis of the 'employment careers', leaving out education, and restricting the observed time range to the age of 20 to 70 years. Seven individuals were removed from the analysis, either because of too much missing data or because the they were too young (under 40 years old) and therefore difficult to compare with the rest of the population. This left us with a sample of 416 careers.

Table 1: Sequence channels

\begin{tabular}{lr}
\hline \hline Channels & States \\
\hline Sector & 6 \\
Sub-sector & 18 \\
Career level (1-8) & 8 \\
Organization size (S - M - L - V) & 4 \\
Geography ('Outside Copenhagen' - 'Copenhagen area' - 'Abroad') & 3 \\
Organization shifts ('Same organization' - 'New organization') & 2 \\
\hline \hline
\end{tabular}

The sector channel was reduced to six broad categories: business, state administration, politics, unions, business associations, and science and education, roughly corresponding to the different institutional orders found in the analysis of the power elite (Larsen \& Ellersgaard 2018) or to the fields on the field of power as described by Bourdieu (1996). Almost exactly half of all states - 1300 of 2597 career years - took place in the business sector, followed by state administration, science and education, with unions, business associations, and politics as the least frequent sectors (see Table A2).

The sub-sector channel has 19 possible states, capturing both differences within and similarities across the sectors. Sub-sectors like commerce and services, and technology and industries, thus, set aside different kinds of business. On the other hand, it connects 'industry-linked unions' to 'industry-linked business'. Similarly, subsectors distinguish between branches of state administration while connecting it to other sectors at sub-sector level. The relationship between sector and sub-sector is displayed in Table 2.

Organizational size was coded as either very large ( +5000 employees or $+100,000$ members), large ( +500 employees or $+10,000$ members or the organization is part of the Danish Elite Network), medium-sized (10- 
500 employees or +1000 members) or small (fewer than 10 employees or 1000 members) in order to capture the weight of the organizations.

Table 2: Number of career years by sector and sub-sector

\begin{tabular}{|c|c|c|c|c|c|c|c|}
\hline \multirow[b]{2}{*}{ Sub-sector } & \multicolumn{6}{|c|}{ Sector } & \multirow[b]{2}{*}{ Total } \\
\hline & Business & $\begin{array}{c}\text { Business } \\
\text { association }\end{array}$ & $\begin{array}{c}\text { State } \\
\text { administration }\end{array}$ & $\begin{array}{l}\text { Science } \\
\text { and } \\
\text { education }\end{array}$ & Politics & Union & \\
\hline Industry \& technology & 2,389 & 337 & & 371 & & 361 & 3,458 \\
\hline Economy \& finance & 1,324 & 137 & 352 & 385 & & 75 & 2,273 \\
\hline $\begin{array}{l}\text { Agriculture \& food } \\
\text { production }\end{array}$ & 370 & 144 & 31 & 65 & & 67 & 677 \\
\hline $\begin{array}{l}\text { Transportation \& } \\
\text { infrastructure }\end{array}$ & 577 & & 71 & & & & 648 \\
\hline Consultancy \& accountancy & 497 & & & & & & 497 \\
\hline Commerce \& services & 385 & 42 & & & & 62 & 489 \\
\hline Business administration & & 76 & 220 & & & & 296 \\
\hline Law & 305 & & 72 & 94 & & & 471 \\
\hline Culture \& media & 271 & & 112 & 80 & & & 463 \\
\hline Health & 329 & & 94 & 76 & & 76 & 575 \\
\hline State administration & & 71 & & 181 & 429 & 91 & 772 \\
\hline Science/education & & 20 & 85 & & & & 105 \\
\hline Military \& police & & & 338 & & & 51 & 389 \\
\hline International organizations & & & 187 & & & & 187 \\
\hline Administration & & & 95 & 190 & & & 285 \\
\hline Local governance & & & 145 & & 203 & 125 & 473 \\
\hline The royal court & & & 184 & & & & 184 \\
\hline Organizations & & & & & 60 & & 60 \\
\hline Educational sector & & & & 330 & & 108 & 438 \\
\hline No subsector & & & & & & 198 & 198 \\
\hline Total & 6,447 & 827 & 1,986 & 1,772 & 692 & 1,214 & 12,938 \\
\hline
\end{tabular}

To capture the progression in career level we found inspiration in previous studies of career sequences (BlairLoy, 1999; Koch, Forgues, \& Monties, 2017). A nine-level scheme was developed: 0: In education; 1: Manual working occupation; 2: White-collar occupation or self-employed; 3: Career position the lowest level, but with access to probable promotion to higher positions, e.g. a junior lawyer or an assistant professor; 4: Leadership position at the lowest level, e.g. a junior manager or a union secretary; 5: Senior leadership position, such as an MP or a professor; 6: Chief executive position in a medium-sized organization or senior management position in a larger organization, e.g. a CEO or a business association director; 7: Chief executive position in a large organization, e.g. a permanent secretary of infrastructure or a university rector; 8: Chief executive position 
in a very large organization, e.g. a prime minister, a monarch or a CEO of a top 50 corporation. Examples of occupations falling into the different career levels based on size and sector of organization are shown in Table

3.

Table A3: Career level and sector codes

\begin{tabular}{|c|c|c|c|c|c|c|c|}
\hline \multirow[b]{2}{*}{$\begin{array}{l}\text { Career } \\
\text { level }\end{array}$} & \multirow[b]{2}{*}{ Position } & \multicolumn{6}{|c|}{ Examples for sectors } \\
\hline & & Business & $\begin{array}{c}\text { Business } \\
\text { association }\end{array}$ & $\begin{array}{c}\text { State } \\
\text { administration }\end{array}$ & $\begin{array}{c}\text { Science and } \\
\text { education }\end{array}$ & Politics & Union \\
\hline 8 & $\begin{array}{l}\text { Leader of a very } \\
\text { large organization }\end{array}$ & $\begin{array}{l}\text { CEO in top } \\
50 \text { firm }\end{array}$ & $\begin{array}{c}\text { CEO, } \\
\text { Confederation } \\
\text { of Danish } \\
\text { Industry }\end{array}$ & $\begin{array}{l}\text { Permanent } \\
\text { secretary, } \\
\text { finance } \\
\text { minister }\end{array}$ & $\begin{array}{l}\text { University } \\
\text { principal in a } \\
\text { very large } \\
\text { university }\end{array}$ & $\begin{array}{l}\text { Prime } \\
\text { minister }\end{array}$ & $\begin{array}{c}\text { President in a } \\
\text { very large } \\
\text { union }\end{array}$ \\
\hline 7 & $\begin{array}{l}\text { Leader of a large } \\
\text { organisation, } \\
\text { leadership in a very } \\
\text { large organisation }\end{array}$ & $\begin{array}{l}\text { CEO in top } \\
200 \text { firm, CE } \\
\text { in top } 50 \text { firm }\end{array}$ & $\begin{array}{l}\text { Executive in } \\
\text { Confederation } \\
\text { of Danish } \\
\text { Industry }\end{array}$ & $\begin{array}{l}\text { Permanent } \\
\text { secretary in } \\
\text { Ministry of } \\
\text { Culture }\end{array}$ & $\begin{array}{c}\text { Principal in a } \\
\text { large } \\
\text { university }\end{array}$ & $\begin{array}{l}\text { Culture } \\
\text { minister, } \\
\text { mayor of } \\
\text { the largest } \\
\text { cities }\end{array}$ & $\begin{array}{c}\text { President in a } \\
\text { large union }\end{array}$ \\
\hline 6 & $\begin{array}{l}\text { Leader in a } \\
\text { medium-sized } \\
\text { organisation, } \\
\text { leadership in a } \\
\text { large organization }\end{array}$ & $\begin{array}{l}\text { CE in top } \\
200 \text { firm, } \\
\text { CEO or } \\
\text { owner in } \\
\text { medium-sized } \\
\text { firm }\end{array}$ & $\begin{array}{l}\text { Executive in } \\
\text { medium-sized } \\
\text { business } \\
\text { association }\end{array}$ & $\begin{array}{l}\text { Director in } \\
\text { state agency, } \\
\text { ambassador }\end{array}$ & $\begin{array}{c}\text { Dean, } \\
\text { professor, } \\
\text { centre leader }\end{array}$ & $\begin{array}{l}\text { Group } \\
\text { leader in } \\
\text { parliament, } \\
\text { mayor of } \\
\text { other cities }\end{array}$ & $\begin{array}{c}\text { Director or } \\
\text { vice chairman } \\
\text { in a very large } \\
\text { union }\end{array}$ \\
\hline 5 & $\begin{array}{l}\text { Managerial } \\
\text { position }\end{array}$ & $\begin{array}{c}\text { Division } \\
\text { director, sales } \\
\text { director, } \\
\text { CEO or } \\
\text { owner in a } \\
\text { small firm }\end{array}$ & $\begin{array}{c}\text { Department } \\
\text { head }\end{array}$ & $\begin{array}{l}\text { Office chief, } \\
\text { municipal } \\
\text { director }\end{array}$ & $\begin{array}{l}\text { Professor, } \\
\text { head of } \\
\text { department }\end{array}$ & MP & $\begin{array}{c}\text { Vice } \\
\text { chairman in a } \\
\text { large union }\end{array}$ \\
\hline 4 & $\begin{array}{l}\text { Junior managerial } \\
\text { position }\end{array}$ & $\begin{array}{l}\text { Project } \\
\text { manager }\end{array}$ & $\begin{array}{c}\text { Senior } \\
\text { consultant }\end{array}$ & Section leader & $\begin{array}{l}\text { Associate } \\
\text { professor }\end{array}$ & Spin doctor & $\begin{array}{c}\text { Union } \\
\text { secretary }\end{array}$ \\
\hline 3 & Career position & $\begin{array}{l}\text { Consultant, } \\
\text { engineer }\end{array}$ & Consultant & $\begin{array}{l}\text { Head of } \\
\text { section }\end{array}$ & $\begin{array}{l}\text { Assistant } \\
\text { professor, } \\
\text { PhD fellow }\end{array}$ & $\begin{array}{l}\text { Personal } \\
\text { secretary }\end{array}$ & $\begin{array}{l}\text { Consultant, } \\
\text { local union } \\
\text { leader }\end{array}$ \\
\hline 2 & $\begin{array}{l}\text { Non-manual } \\
\text { position with little } \\
\text { chance of } \\
\text { progression to a } \\
\text { higher level }\end{array}$ & Secretary & Clerk & Secretary & $\begin{array}{l}\text { Technician, } \\
\text { teacher }\end{array}$ & Clerk & Clerk \\
\hline 1 & $\begin{array}{l}\text { Manual position } \\
\text { with little chance } \\
\text { of progression to a } \\
\text { higher level }\end{array}$ & Metalworker & & & Janitor & & \\
\hline 0 & $\begin{array}{l}\text { In education (no } \\
\text { sector) }\end{array}$ & & & & & & \\
\hline
\end{tabular}


The rbythm of organizational shifts is identified as succession of two different states: 'new organization', when an organization is entered, or 'same organization', if it is the same as the year before.

Career geography is recorded in three possible states: provinces (outside the capital region), the capital region, and abroad.

All codes have been tested for inter-coder reliability, and all values have been checked by at least two of the researchers. An example of the coding of careers is found in the Appendix A, in which the careers of the pair of most similar, of the pair of most different and of the two most central individuals of the Danish Elite Network are shown.

\section{Analysis: Developing a typology of careers}

\section{Measuring distance}

Having defined the possible states within each sequence channel, we need a good measure of the distance between the different sequences to develop reasonable and well-founded typologies and taxonomies, a craft that has been a driving force in the development of all the empirical sciences (Benzécri, 1973). Here we apply the optimal matching technique (Lesnard, 2014; Macindoe \& Abbott, 2004). As opposed to distances based on state distributions or counts of common attributes, the optimal matching (OM) distance is a so-called edit distance (Ritschard \& Studer, 2016). That is, the degree of difference or similarity between two distinct careers amounts to the cost of transforming one sequence into the other. The transformation of sequences can be done with three different 'edit-operations'; i.e. by substituting, inserting, or deleting states. As there are often many ways of 'aligning' to sequences, the 'cheapest' or optimal solution determines the distance, i.e. the one requiring least edits. However, since not all states within a channel are equally similar or different (state administration may or may not be more similar to politics than to business), we need to define the relative similarity of the states; a major methodological challenge in any OM procedure (Gauthier, Widmer, Bucher, \& Notredame, 2009; Lesnard, 2010, 2014). Having no prior knowledge of the relative similarity, we rely here on costs that are empirically generated from probabilities in our data. The cost of substituting one state for another in order to align two sequences is low when it is empirically likely to go from the one state to the other in a career, and higher when the shift from the one state to the other is less likely.

One thing is setting the cost of substituting one state or event with another and the cost of insertions and deletions; another is balancing the ratio between substitution and insertion and deletion costs. This ratio determines the weight given in the analysis to either timing or order (Lesnard, 2014). When the substitution cost is larger than the insertion and deletion costs, the comparing of sequences amounts to the insertions and deletions needed to find the longest common sub-string, whereas the comparison, when insertion and deletion costs are larger than the substitution cost, becomes a kind of event approximation. In this analysis, we have 
chosen a 'cost scheme' trying to balance out the two extremes by setting a constant insertion and deletion cost at 1.1, i.e. a bit higher than half the maximum substitution cost, which is 2 . There is, however, one important exception. The cost of substituting missing states in the new organization versus that in the same organization channel is set to 2.3, which is more than one insertion + one deletion, which means it will never be used, as it is always less costly to insert and empty the slot in this sequence and delete the missing slot in the other.

The relatively recent development of multichannel sequence analysis (Gauthier, Widmer, Bucher, \& Notredame, 2010) makes it possible to study all the relevant characteristics of the careers simultaneously, thus integrating the interaction between channels in the analysis. Based on the individual trajectory in these six channels, two measures of diversity can be calculated, i.e. turbulence and internal entropy. While the turbulence measure captures career volatility, i.e. the diversity and varying length of states in a sequence (Elzinga \& Liefbroer, 2007), entropy represents the 'uncertainty' of predicting the states in a sequence (Gabadinho, Ritschard, Studer, \& Müller, 2011, p. 78). In a sequence with low entropy, we have good chances of guessing the next career move based on the previous one. Complexity is measured based on the number of distinct subsequences and the variance of durations within these (Elzinga, 2010). Examples of the distances are found in Appendix A.

\section{Grouping the similar}

To construct the typology of career paths presented in the article, we relied on the principle of hierarchical agglomerative clustering (HAC). On the basis of a Euclidean distance measure, the optimal matching editdistance, between all pairs of career trajectories, groups of individuals (i.e. their careers) are created in successive steps using the Ward criterion, which groups units in a way that in each step minimizes the increase in internal variance within groups in relation to the variance between groups (Ward, 1963). In our analysis, we both look at the two overall branches of this cluster and four and six clusters nested within these clusters. Inspecting the structure of the tree, we find a fundamental distinction between private and public pathways to power (see Figure 1). The first cluster is tied to careers in the private sector $(n=212)$ and has four sub-clusters: 'the landed gentry', the 'bankers', the 'industrial inner circle' and the 'corporate ambassadors'. The second main cluster is tied to careers located mainly in the public sector or in interest organisations $(n=204)$ and has six sub-clusters: 'education and local politics', the 'scientists', the 'unionists', the 'state nobility', 'professional politicians' and the 'lobbyists'. We arrive at the ten cluster due by heuristics - there is a sociologically interpretable differentiation between clusters - and by assessing the ratio of the between-cluster-variance, or the variance of cluster mean points, to the total variance of optimal matching distances. Identifying 10 clusters yields a correlation ratio of $\eta^{2}=0.335$, i.e. one-third of the total variance is 'explained' by the 10 clusters. Furthermore, as seen by Figure 2 , the marginal benefit of including more clusters to account for more of the total variance - not to speak of the difficulties of reporting about each cluster - decrease when choosing more than around 10 clusters (27 clusters is needed to explain $50 \%$ ). 
Figure 1: Hierarchical agglomerative cluster analysis dendrogram of the 10 clusters

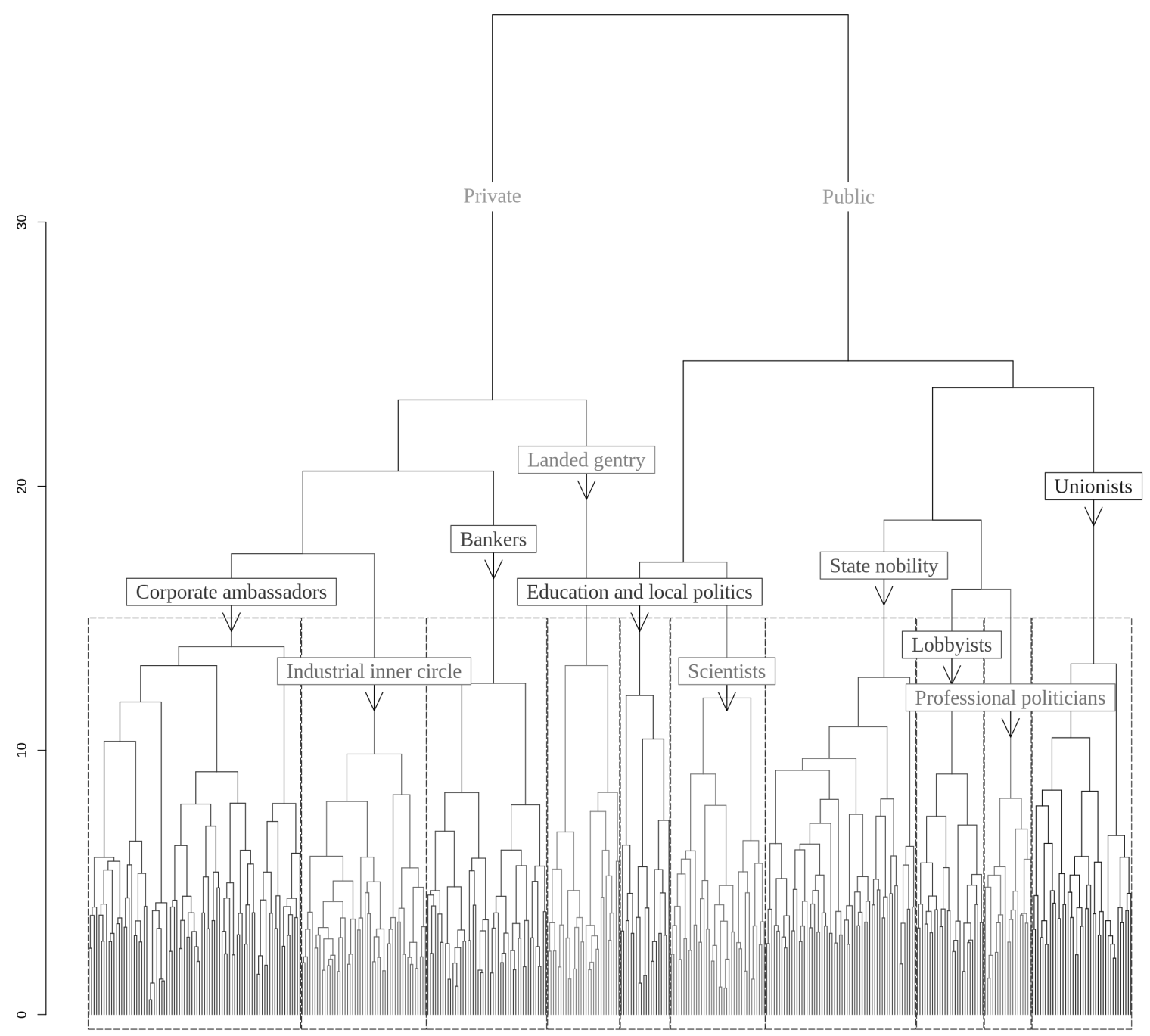


Figure 2: Ratio of between variance to total variance depending on number of clusters
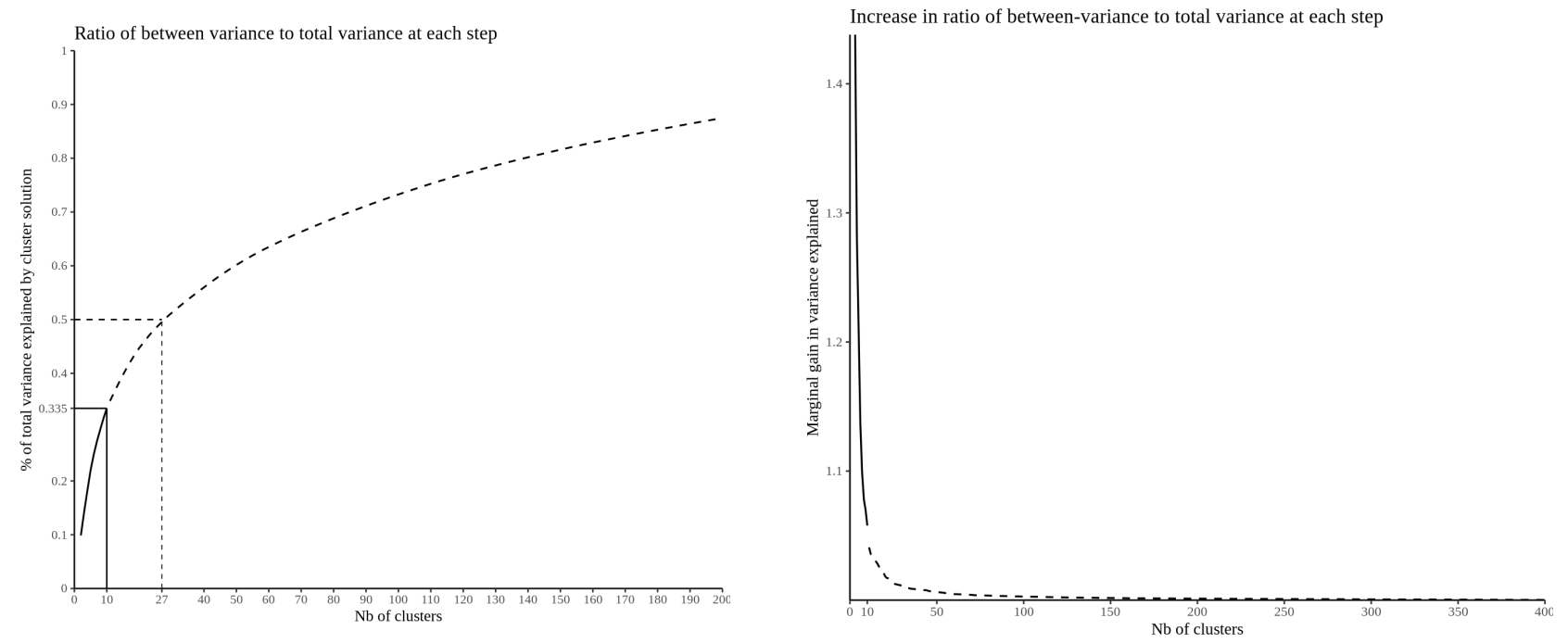

Figure 3: Career progression per cluster

Proportion at level 7+ (cumulated)
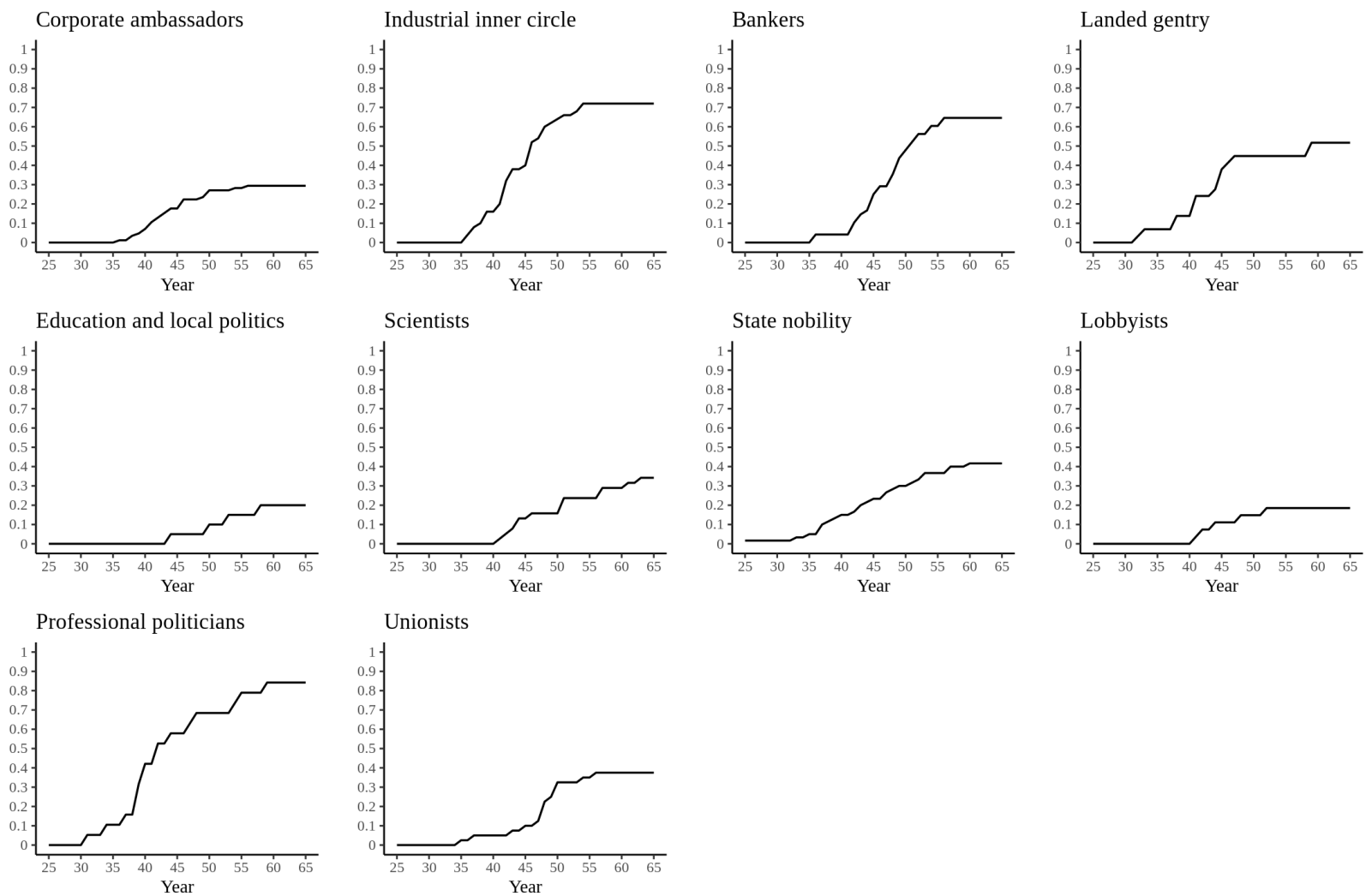
To explore the homogeneity and diversity in the 10 clusters identified in the analysis, progression in career by age can be seen by career level in Figure 3 and by the six channels - sector, subsector, organizational size, organization location, career level and career changes - in Figure Appendix B. Characteristics of each cluster are described in Appendix C. We identified significant deviations between the group mean and the global mean on a range of characteristics, related to both career traits and other biographical information such as type and length of education and parental background. Test-values were calculated as proposed by Lebart, Morineau and Piron (2006), where absolute values above 2 indicate a significant difference between the group mean (or frequency) and the global mean (or frequency).

\section{Concluding remarks}

This paper have provided examples on how to collect, code and through multichannel sequence analysis develop typologies of elites careers. We use the careers of 426 members of the Danish power elite as empirical case. We argue that a solution identifying two main clusters, and four and six subclusters within these clusters best serves as heuristics to develop a typology for elite careers. Furthermore, we show how to characterize the clusters based on the variables included in the sequence analysis and descriptive characteristics of the individuals. 


\section{References:}

Abbott, A., \& Hrycak, A. (1990). Measuring Resemblance in Sequence Data: An Optimal Matching Analysis of Musicians' Careers. American Journal of Sociology, 96(1), 144-185.

Araujo, P. (2018). Dynamics of Internationalism: A Sequential Analysis of the Careers of Swiss Banking Elites. In O. Korsnes, J. Heilbron, J. Hjellbrekke, F. Bühlmann \& M. Savage (Eds.) New Directions in Elite Studies, (pp. 73-89). London: Routledge.

Benzécri, J.-P. (1973). La taxinomie. Paris: Dunod.

Blair-Loy, M. (1999). Career Patterns of Executive Women in Finance: An Optimal Matching Analysis. American Journal of Sociology, 104(5), 1346-1397.

Bourdieu, P. (1996). State Nobility - Elite Schools in the Field of Power. Cambridge: Polity Press.

Bühlmann, F. (2008). The Corrosion of Career?_-Occupational Trajectories of Business Economists and Engineers in Switzerland. European Sociological Review, 24(5), 601-616.

Elzinga, C. H. (2010). Complexity of Categorical Time Series. Sociological Methods \& Research, 38(3), 463-481.

Elzinga, C. H., \& Liefbroer, A. C. (2007). De-standardization of Family-Life Trajectories of Young Adults: A Cross-National Comparison Using Sequence Analysis: Dé-standardisation des trajectoires de vie familiale des jeunes adultes: comparaison entre pays par analyse séquentielle. European Journal of Population / Revue Européenne de Démographie, 23(3-4), 225-250.

Gabadinho, A., Ritschard, G., Studer, M., \& Müller, N. S. (2011). Mining sequence data in R with the TraMineR package: A users guide for version 1.8. Geneva: University of Geneva.

Gauthier, J.-A., Widmer, E. D., Bucher, P., \& Notredame, C. (2009). How Much Does It Cost?: Optimization of Costs in Sequence Analysis of Social Science Data. Sociological Methods \& Research, 38(1), 197-231.

Koch, M., Forgues, B., \& Monties, V. (2017). The Way to the Top: Career Patterns of Fortune 100 CEOS. Human Resource Management, 56(2), 267-285.

Larsen, A. G., \& Ellersgaard, C. H. (2017). Identifying power elites-k-cores in heterogeneous affiliation networks. Social Networks, 50, 55-69.

Larsen, A. G., \& Ellersgaard, C. H. (2018). A Scandinavian Variety of Power Elites? - Key Institutional Orders in the Danish Elite Networks. In O. Korsnes, J. Heilbron, J. Hjellbrekke, F. Bühlmann, \& M. Savage (Eds.) New Directions in Elite Research, (pp. 133-49. London: Routledge.

Lebart, L., Morineau, A., \& Piron, M. (2006). Statistique exploratoire multidimensionnelle: visualisations et inférences en fouilles de données: Cours et exercices corrigés. Paris: Dunod.

Lesnard, L. (2010). Setting Cost in Optimal Matching to Uncover Contemporaneous Socio-Temporal Patterns. Sociological Methods \& Research, 38(3), 389-419.

Lesnard, L. (2014). Using Optimal Matching Analysis in Sociology: Cost Setting and Sociology of Time. In P. Blanchard, F. Bühlmann, \& J.-A. Gauthier (Eds.), Advances in Sequence Analysis: Theory, Method, Applications (pp. 39-50). Springer International Publishing. 
Macindoe, H., \& Abbott, A. (2004). Sequence Analysis and Optimal Matching Techniques for Social Science Data. In M. Hardy \& A. Bryman, Handbook of Data Analysis (pp. 386-406). London: Sage.

Ohmura, T., Bailer, S., Meißner, P., \& Selb, P. (2018). Party animals, career changers and other pathways into parliament. West European Politics, 41(1), 169-195.

Ritschard, G., \& Studer, M. (2016). What matters in differences between life trajectories: a comparative review of sequence dissimilarity measures. Journal of the Royal Statistical Society. Series A, Statistics in Society, 179(2), 481-511.

Seabrooke, L., \& Nilsson E. R. (2015). Professional Skills in International Financial Surveillance: Assessing Change in IMF Policy Teams. Governance, 28(2): 237-54

Stovel, K., Savage, M., \& Bearman, P. (1996). Ascription into Achievement: Models of Career Systems at Lloyds Bank, 1890-1970. American Journal of Sociology, 102(2), 358-399.

Ward, J. H. (1963). Hierarchical Grouping to Optimize an Objective Function. Journal of the American Statistical Association, 58(301), 236-244. https://doi.org/10.2307/2282967 


\section{Appendix A: Examples of career coding}

\begin{tabular}{|c|c|c|c|c|c|c|c|c|}
\hline Sector & Subsector & Region & Organization & Size & Position & $\begin{array}{c}\text { Career } \\
\text { level }\end{array}$ & Start & End \\
\hline \multicolumn{9}{|c|}{ Example 1: The two most similar careers $(\mathrm{OM}$-distance $=0.56)$} \\
\hline \multicolumn{9}{|l|}{ Oluf Christian Engell } \\
\hline Business & Law & Capital region & Bruun \& Hjejle & $\mathrm{L}$ & Lawyer & 4 & 1971 & 1975 \\
\hline Business & Law & Capital region & Bruun \& Hjejle & $\mathrm{L}$ & Partner & 5 & 1976 & 2013 \\
\hline \multicolumn{9}{|c|}{ Henrik. Mogens Wedell-Wedellsborg } \\
\hline Business & Law & Capital region & Gorissen Federspiel & $\mathrm{L}$ & Lawyer & 4 & 1970 & 1972 \\
\hline Business & Law & Abroad & Gide Loyrette Nouel & $\mathrm{L}$ & Law assistant & 3 & 1973 & 1974 \\
\hline Business & Law & Capital region & Gorissen Federspiel & $\mathrm{L}$ & Partner & 5 & 1975 & 1979 \\
\hline Business & Law & Capital region & Bruun \& Hjejle & $\mathrm{L}$ & Partner & 5 & 1980 & 2013 \\
\hline \multicolumn{9}{|c|}{ Example 2: The two least similar careers $(\mathrm{OM}-$ distance $=9.3)$} \\
\hline \multicolumn{9}{|l|}{ Kim Koch Boyter } \\
\hline Business & Industry \& technology & Provinces & Pressalit Group & M & Employee & 2 & 1988 & 1989 \\
\hline Business & Industry \& technology & Abroad & Pressalit Group & M & Employee & 2 & 1990 & 1992 \\
\hline Business & Industry \& technology & Abroad & Pressalit Group & M & Employee & 2 & 1993 & 1998 \\
\hline Business & Industry \& technology & Provinces & Pressalit Group & M & CEO (and owner) & 5 & 1999 & 2013 \\
\hline \multicolumn{9}{|l|}{ Flemming Vinther } \\
\hline Business & Commerce \& services & Provinces & Matas & $\mathrm{L}$ & Shop assistant & 1 & 1983 & 1983 \\
\hline State administration & Military \& police & Capital region & The Royal Life Guards & $\mathrm{L}$ & Conscripted soldier & & 1984 & 1984 \\
\hline Business & Commerce \& services & Provinces & Matas & $\mathrm{L}$ & Shop assistant & 1 & 1985 & 1985 \\
\hline State administration & Military \& police & Capital region & The Danish army & $\mathrm{V}$ & Contract soldier & 1 & 1986 & 1995 \\
\hline Union & Military \& police & Capital region & HKKF & $\mathrm{L}$ & Union secretary & 4 & 1996 & 2003 \\
\hline Union & Military \& police & Capital region & $\mathrm{HKKF}$ & $\mathrm{L}$ & Union leader & 6 & 2004 & 2013 \\
\hline \multicolumn{9}{|c|}{ Example 3: Careers of the two most central individuals in the elite network $(\mathrm{OM}$-distance $=6.49)$} \\
\hline \multicolumn{9}{|l|}{ Thorkild Engell Jensen } \\
\hline Business & Industry \& technology & Provinces & Vølund & M & Blacksmith & 1 & 1972 & 1984 \\
\hline Union & Industry \& technology & Provinces & Dansk Metal & $\mathrm{L}$ & Local union leader & 3 & 1985 & 1991 \\
\hline Union & Industry \& technology & Capital region & Dansk Metal & $\mathrm{L}$ & Union secretary & 4 & 1992 & 1992 \\
\hline Union & Industry \& technology & Capital region & Dansk Metal & $\mathrm{L}$ & Union secretary & 5 & 1993 & 1993 \\
\hline Union & Industry \& technology & Capital region & Dansk Metal & $\mathrm{L}$ & Union vice-president & 6 & 1994 & 2002 \\
\hline Union & Industry \& technology & Capital region & Dansk Metal & $\mathrm{L}$ & Union leader & 8 & 2003 & 2012 \\
\hline \multicolumn{9}{|l|}{ Lars Norby Johansen } \\
\hline Science/education & State administration & Provinces & University of Southern Denmark & $\mathrm{L}$ & Assistant professor & 3 & 1974 & 1976 \\
\hline Science/education & State administration & Abroad & EUI & $\mathrm{V}$ & Assistant professor & 3 & 1977 & 1979 \\
\hline Science/education & State administration & Provinces & University of Southern Denmark & $\mathrm{L}$ & Assistant professor & 3 & 1980 & 1981 \\
\hline Science/education & State administration & Abroad & Harvard University & $\mathrm{V}$ & Associate professor & 4 & 1982 & 1982 \\
\hline Science/education & State administration & Capital region & Danmarks Forvaltningshøjskole & M & Consultant & 4 & 1983 & 1985 \\
\hline Business association & Economy \& finance & Capital region & Forsikring og Pension & $\mathrm{L}$ & Assistant director & 5 & 1986 & 1986 \\
\hline Business & Economy \& finance & Capital region & Tryg & $\mathrm{V}$ & Assistant director & 5 & 1987 & 1988 \\
\hline Business & Commerce \& services & Capital region & Falck & $\mathrm{L}$ & $\mathrm{CEO}$ & 7 & 1989 & 2005 \\
\hline Business & - & - & - & - & Board chairman & 8 & 2006 & 2013 \\
\hline
\end{tabular}




\section{Appendix B: Sector, subsector, career level, organization size, location and career changes sequences by cluster}

Figure B1: Sector
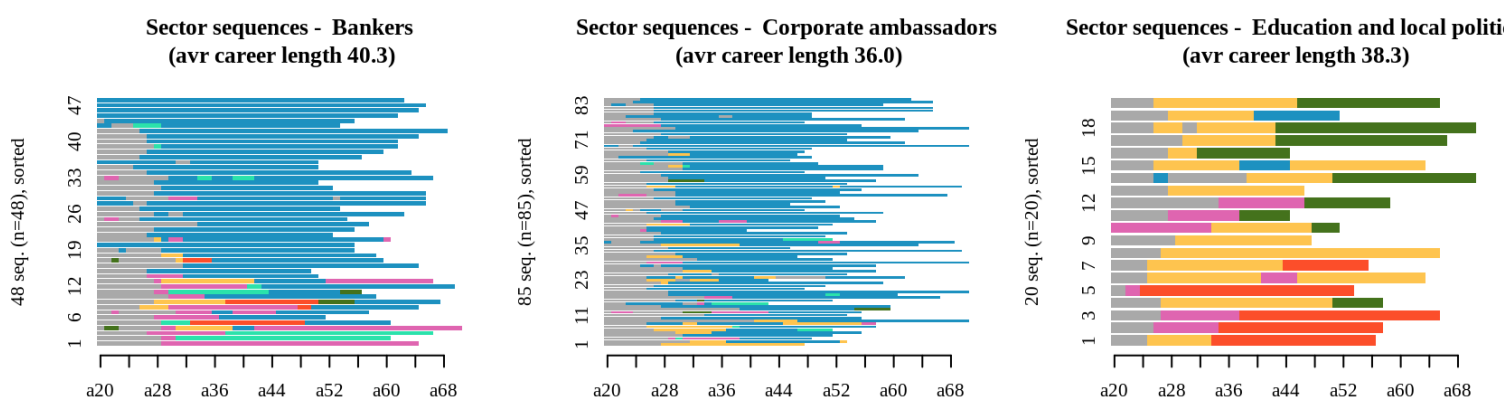

Sector sequences - Industrial inner circle

Sector sequences - Landed gentry (avr career length 39.0)

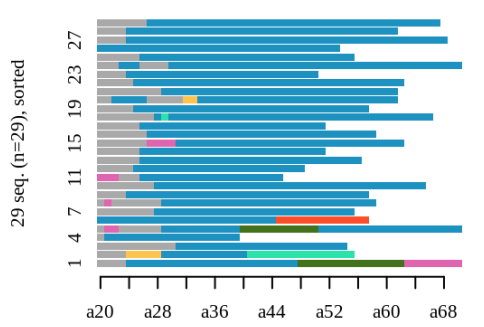

Sector sequences - Lobbyists

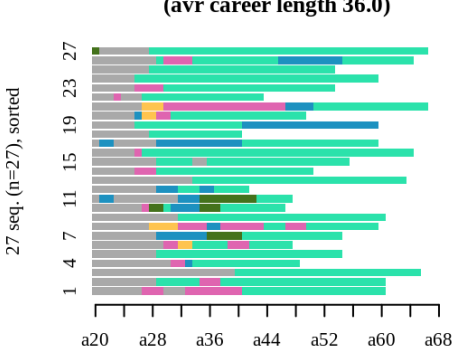

Sector sequences - Professional politicians (avr career length 35.9)
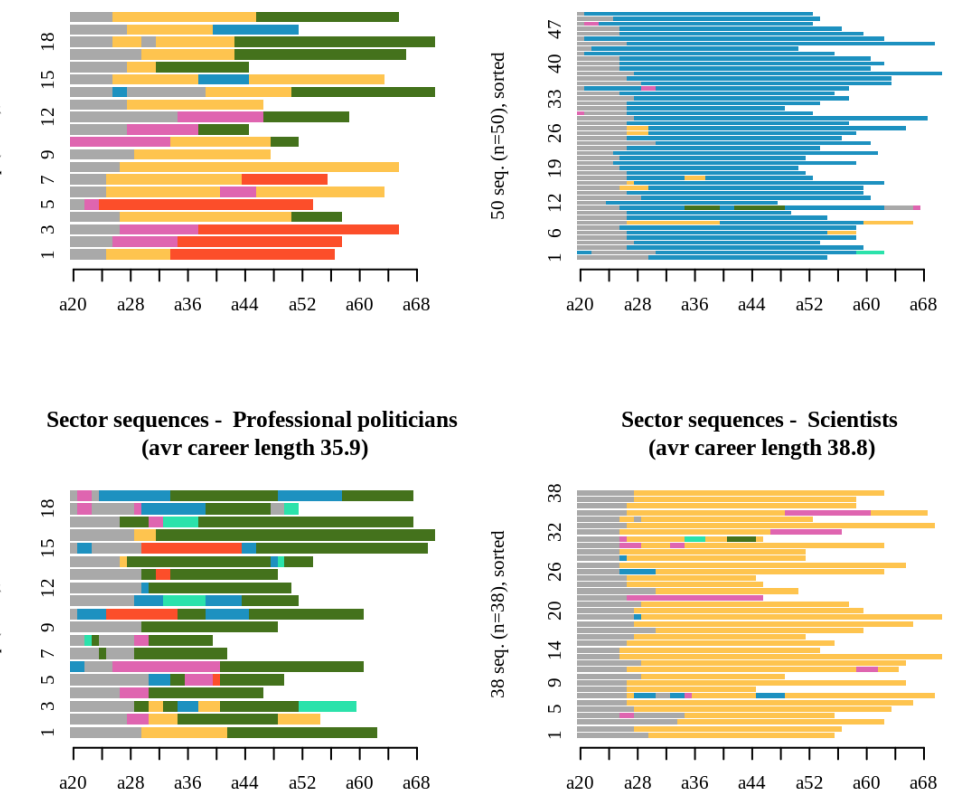

Sector sequences - Scientists

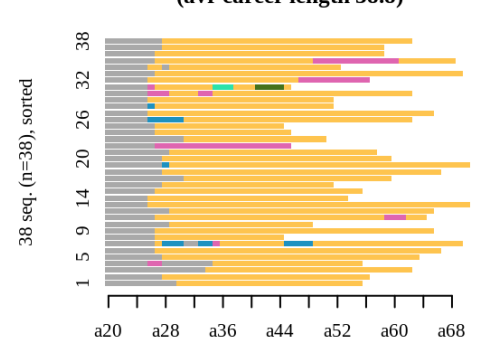

Sector sequences - State nobility (avr career length 39.1)

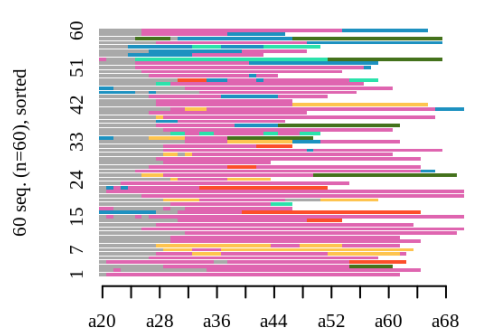

Sector sequences - Unionists (avr career length 39.6)

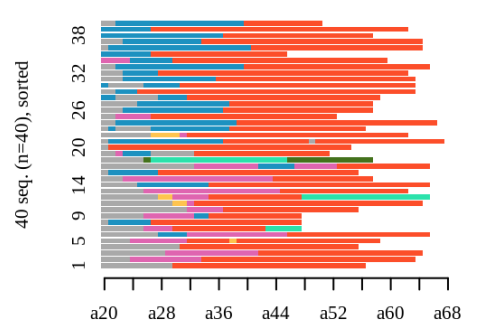


Figure B2: Subsector

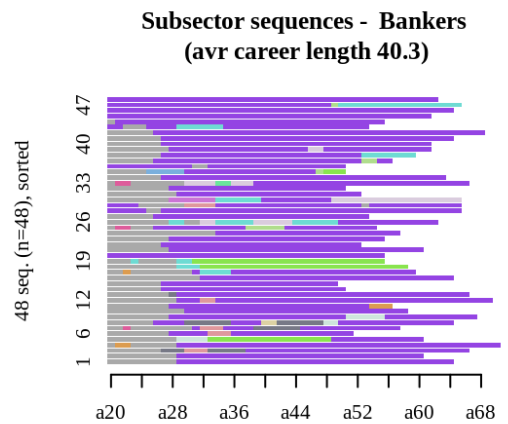

Subsector sequences - Landed gentry (avr career length 39.0 )

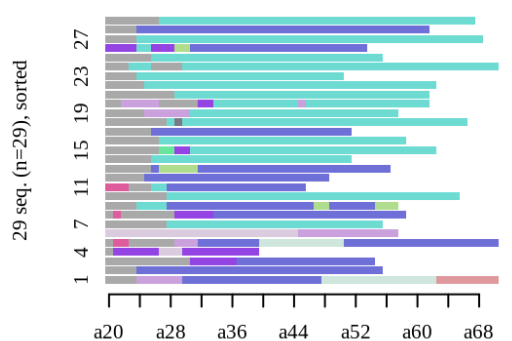

Subsector sequences - State nobility (avr career length 39.1)

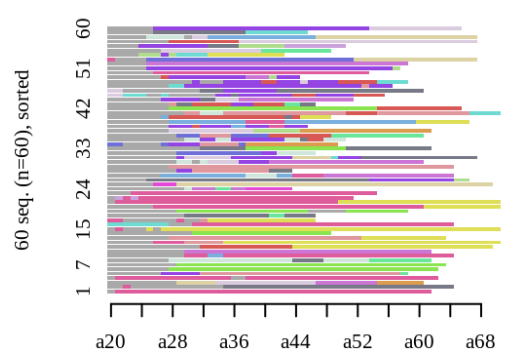

Subsector sequences - Corporate ambassadors Subsector sequences - Education and local politic (avr career length 36.0)

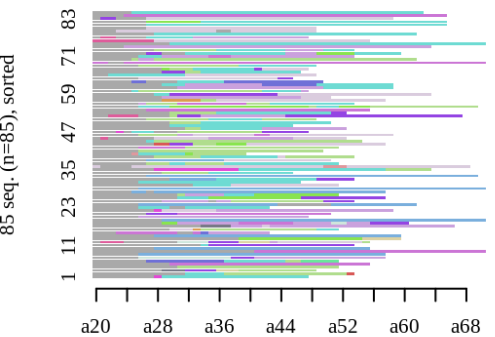

Subsector sequences - Lobbyist (avr career length 36.0 )

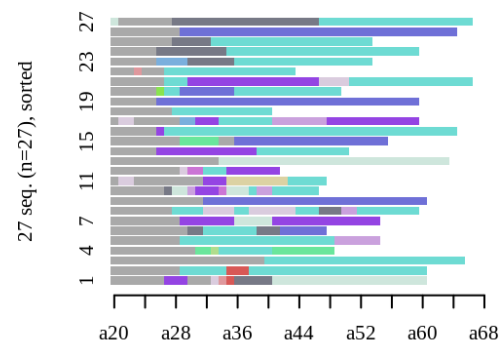

Subsector sequences - Unionists (avr career length 39.6)

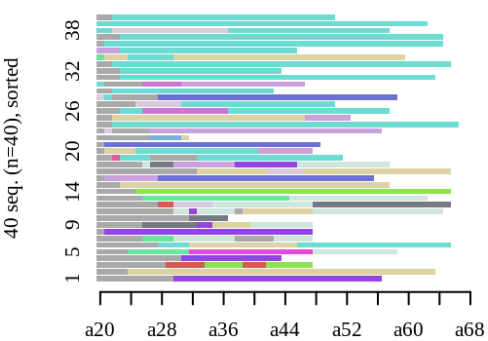

Subsector sequences - Professional politicians (avr career length 38.3)

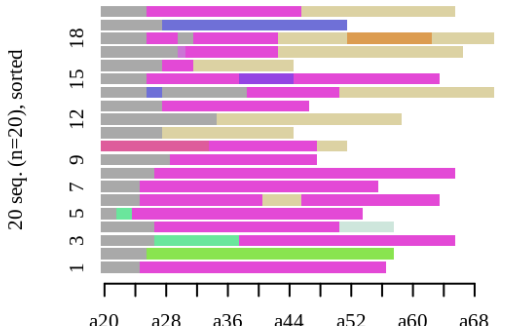
(avr career length 35.9)
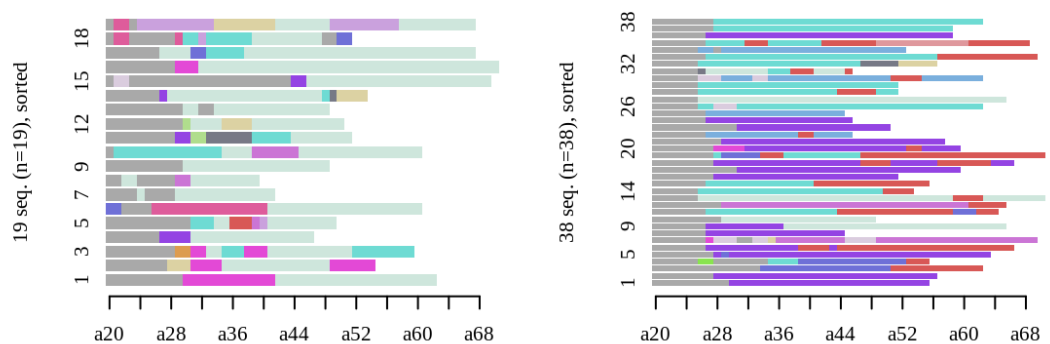

(avr career length 38.5)

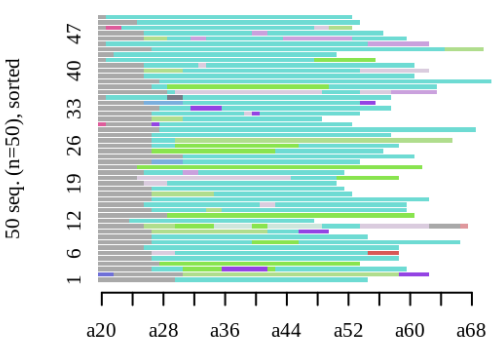

Subsector sequences - Scientists (avr career length 38.8)

$$
\begin{aligned}
& \text { 믈 Administration } \\
& \text { B Commerce and Service } \\
& \text { Consultancy and accountancy } \\
& \begin{array}{l}
\text { Culture and Media } \\
\text { Economy and Finance }
\end{array} \\
& \text { Educational sector } \\
& \text { Industry and Technology } \\
& \text { International organizations } \\
& \text { Law } \\
& \text { Local governance } \\
& \text { O Organisationer } \\
& \text { G Science/Education } \\
& \text { State administration } \\
& \begin{array}{l}
\text { The Royal Court } \\
\text { Transportation and infrastructure }
\end{array}
\end{aligned}
$$


Figure B3: Career level
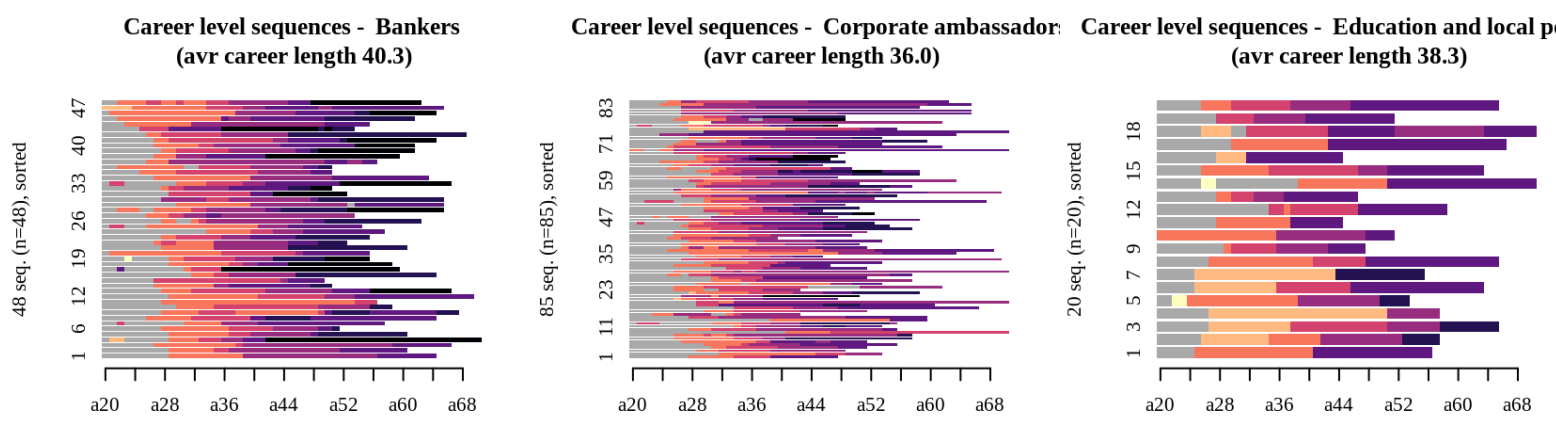

Career level sequences - Industrial inner circle (avr career length 40.3)

Career level sequences - Landed gentry (avr career length 39.0)

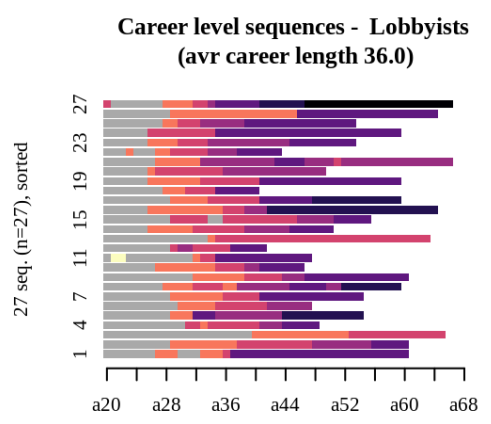

Career level sequences - Professional politicians (avr career length 35.9)
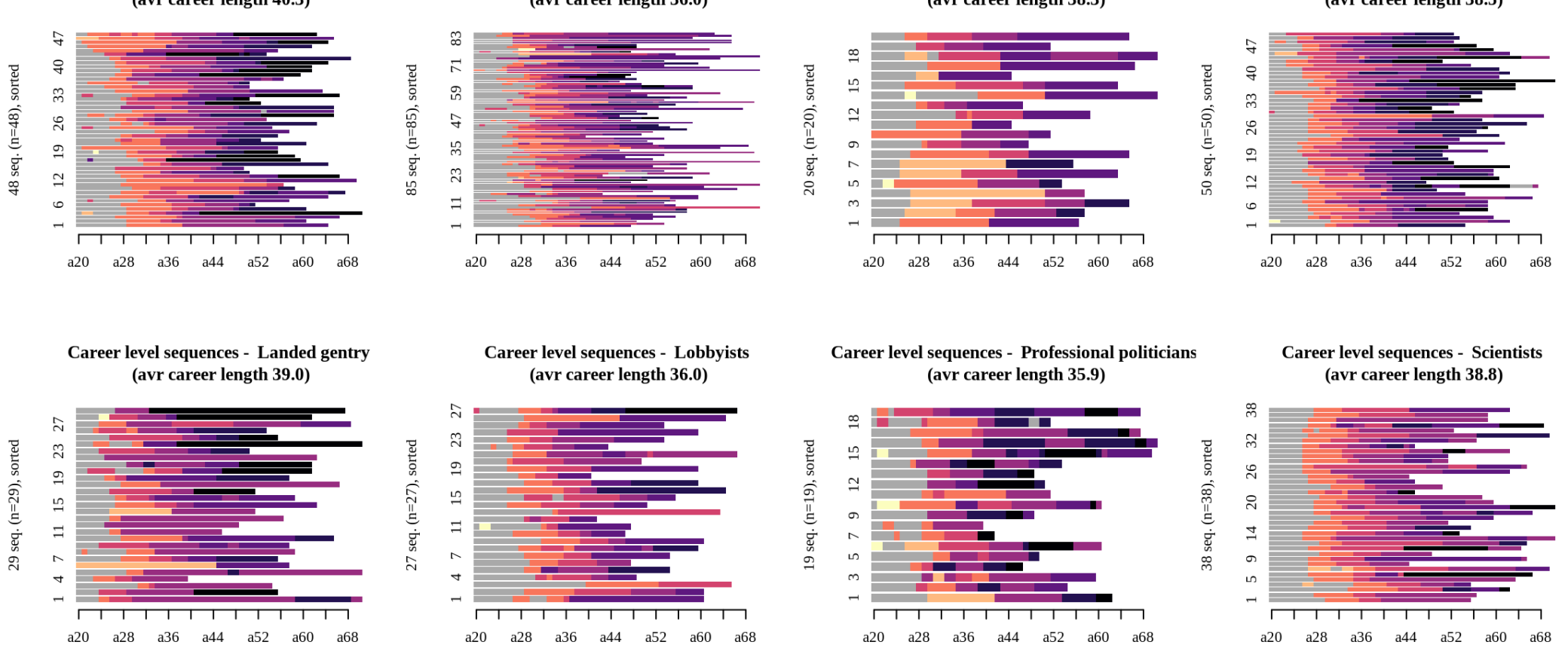

Career level sequences - State nobility (avr career length 39.1)

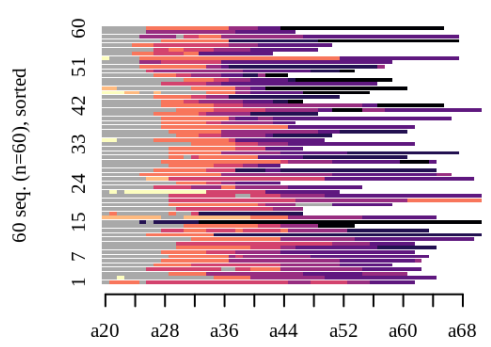

Career level sequences - Unionists (avr career length 39.6 )
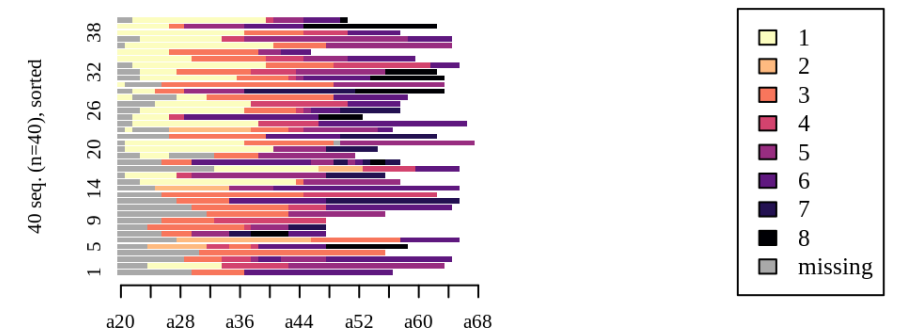
Figure B4: Organization Size

Organisation size sequences - Bankers (avr career length 40.3)

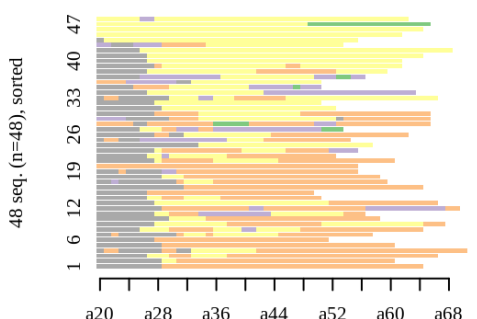

Organisation size sequences - Landed gentry (avr career length 39.0)

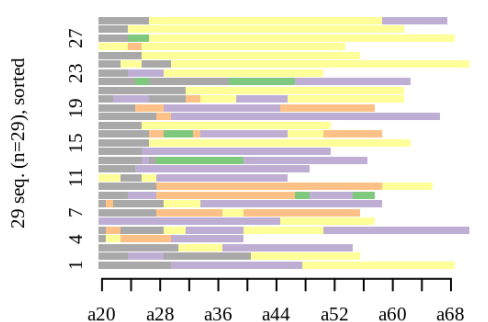

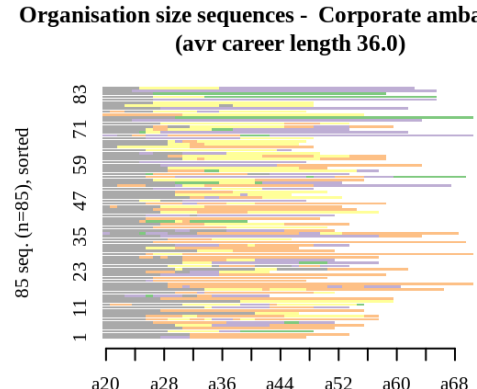

Organisation size sequences - Lobbyist (avr career length 36.0)

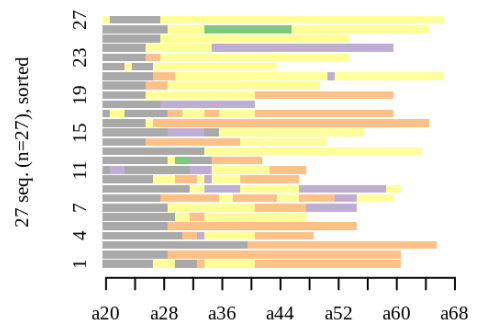

Organisation size sequences - Unionist (avr career length 39.6)

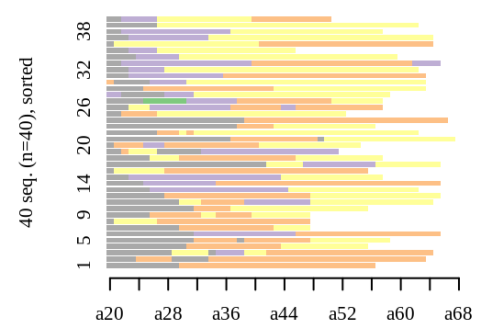

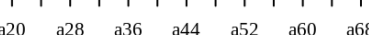
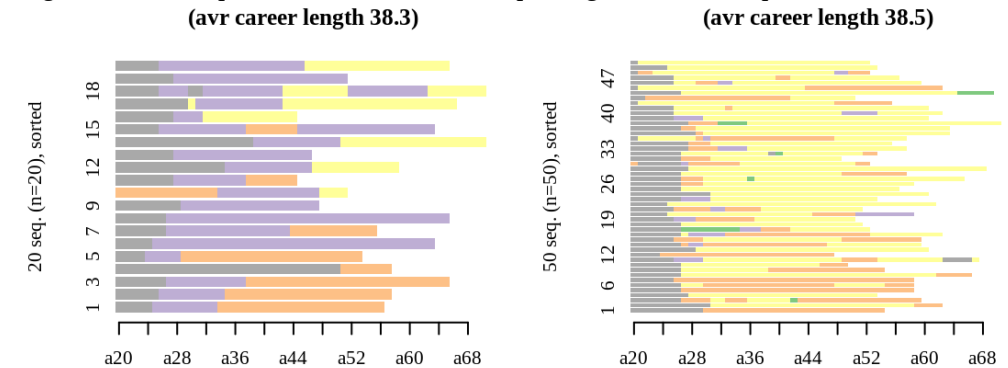

Organisation size sequences - Professional politici (avr career length 35.9)
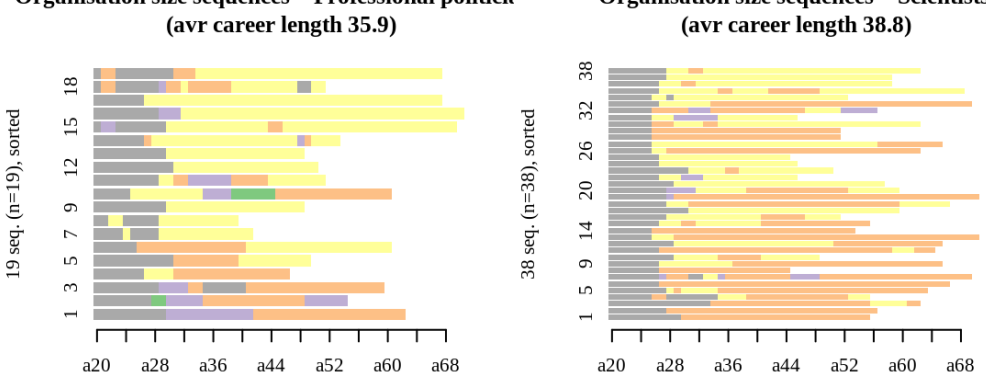

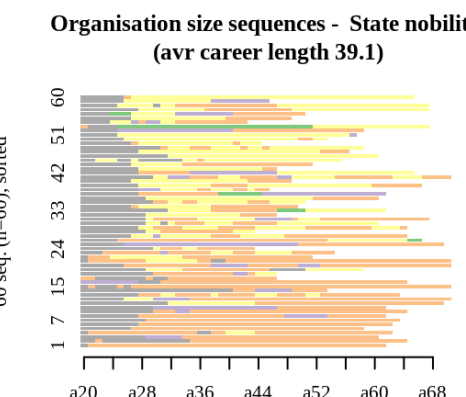


Figure B5: Organizational location

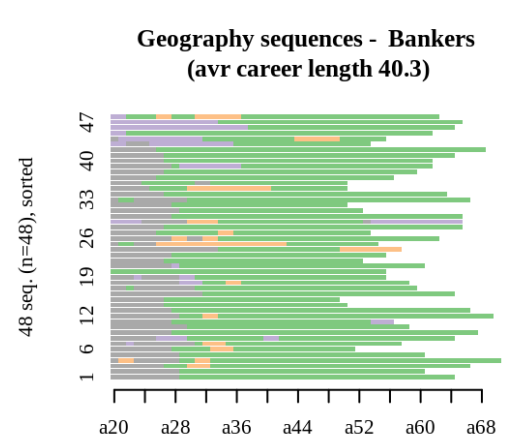

Geography sequences - Landed gentry (avr career length 39.0)

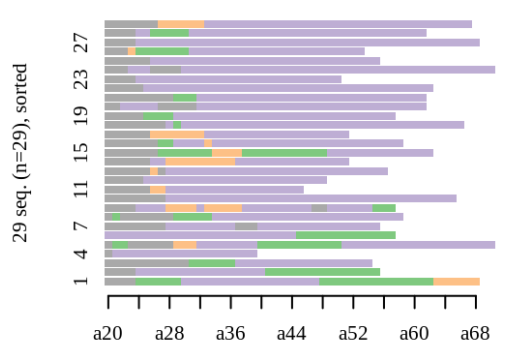

Geography sequences - State nobility (avr career length 39.1)

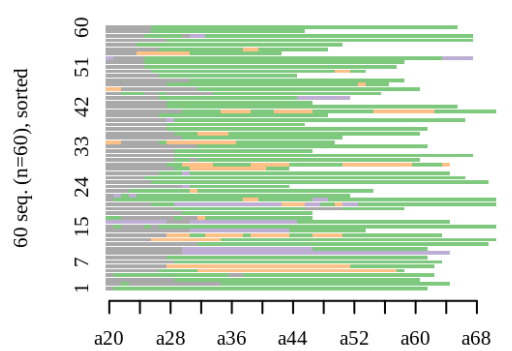

Geography sequences - Corporate ambassadors Geography sequences - Education and local politi (avr career length 36.0)

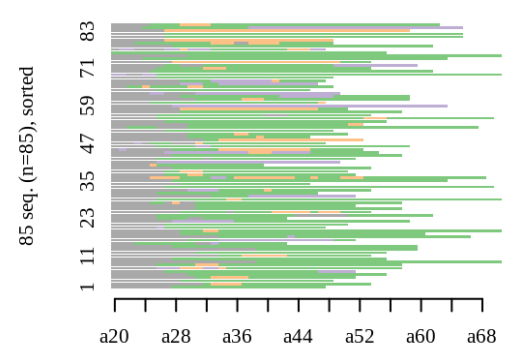

Geography sequences - Lobbyists (avr career length 36.0)

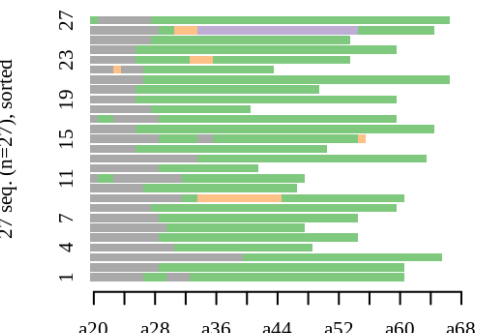

Geography sequences - Unionists (avr career length 39.6 )

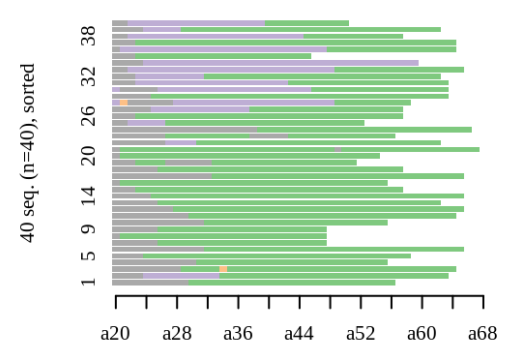

$\square$ Greater Copenhagen Area

$\square$ Outside the Greater Copenhagen Area

$\square$ Abroad

$\square$ missing (avr career length 38.3)

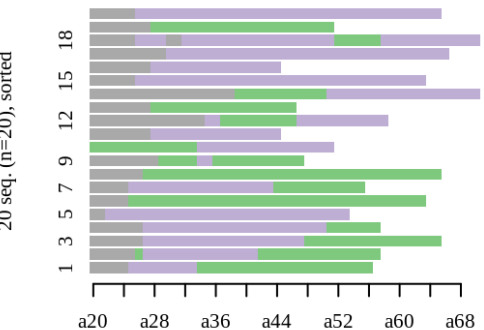

Geography sequences - Professional politicians (avr career length 35.9)
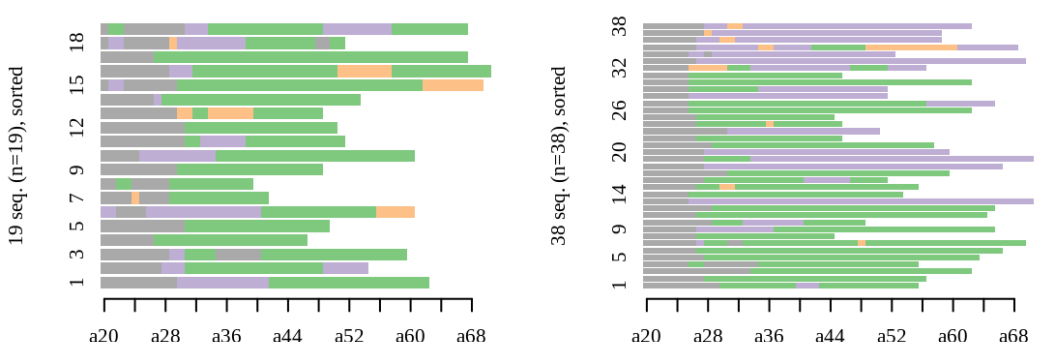

Geography sequences - Industrial inner circle (avr career length 38.5)

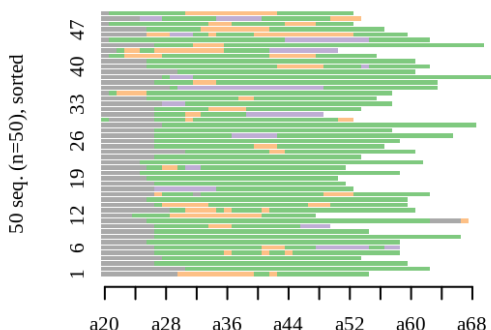

Geography sequences - Scientists (avr career length 38.8) 
Figure B6: Organizational shifts
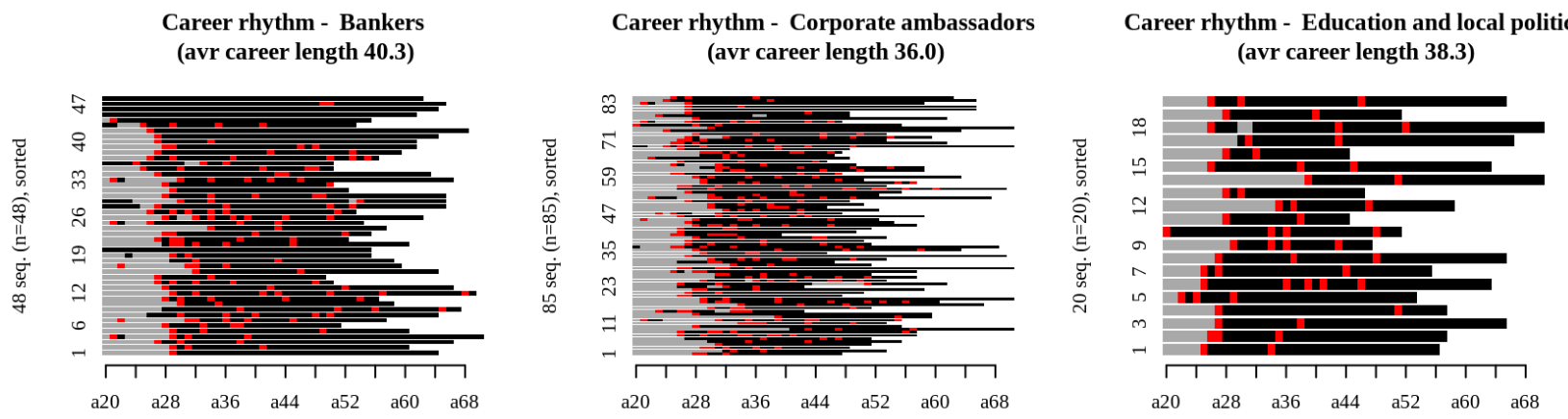

Career rhythm - Industrial inner circle (avr career length 38.5)

Career rhythm - Landed gentry (avr career length 39.0)

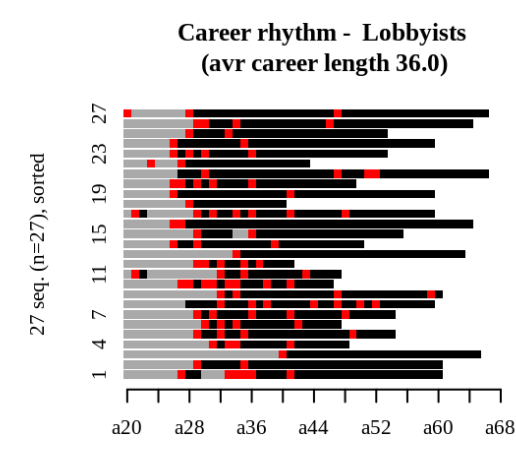

Career rhythm - Professional politicians (avr career length 35.9)
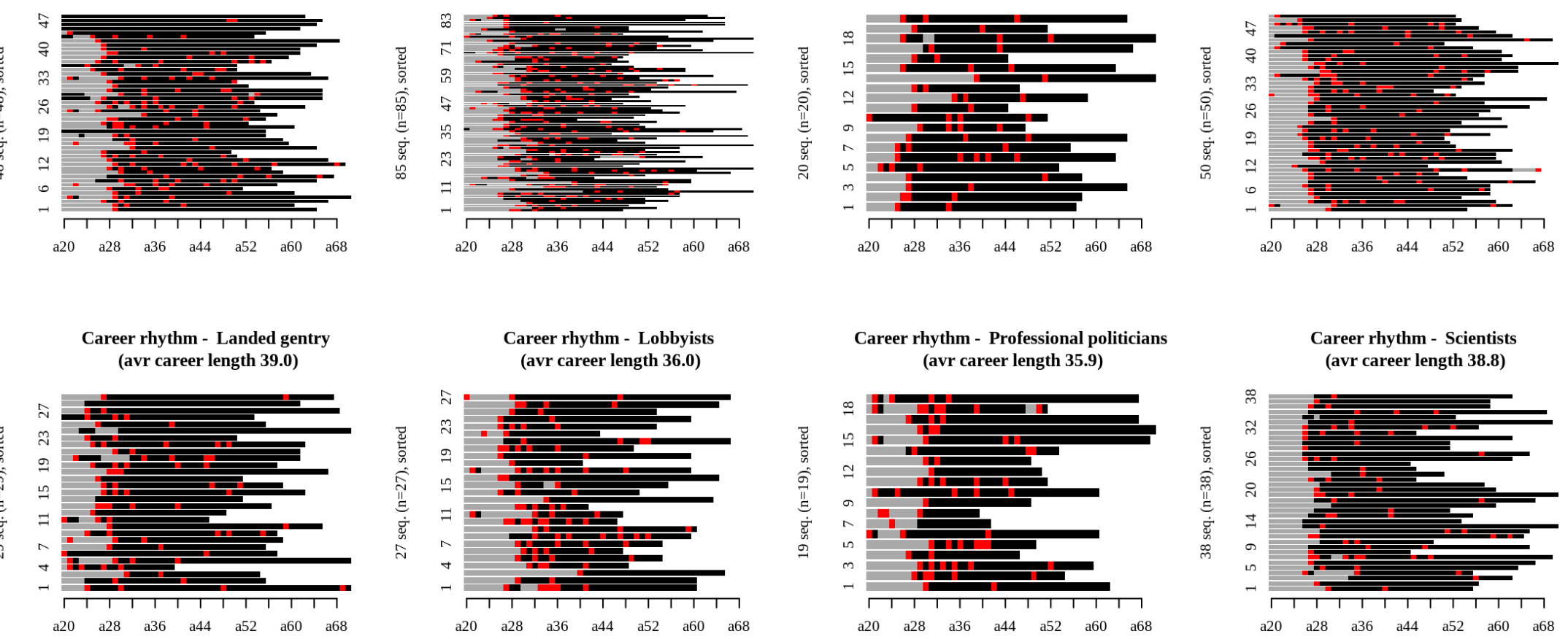

Career rhythm - State nobility (avr career length 39.1)

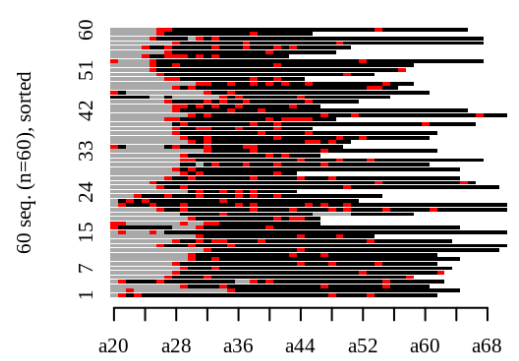

Career rhythm - Unionists (avr career length 39.6)

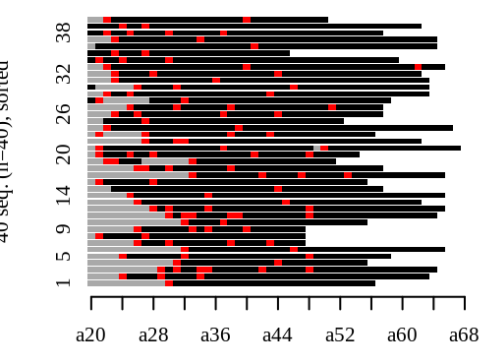

ㅁ. New org

missing

$\begin{array}{lllllll}\text { a20 } & \text { a28 } & \text { a36 } & \text { a44 } & \text { a52 } & \text { a60 } & \text { a68 }\end{array}$
Career rhythm - Scientists (avr career length 38.8)

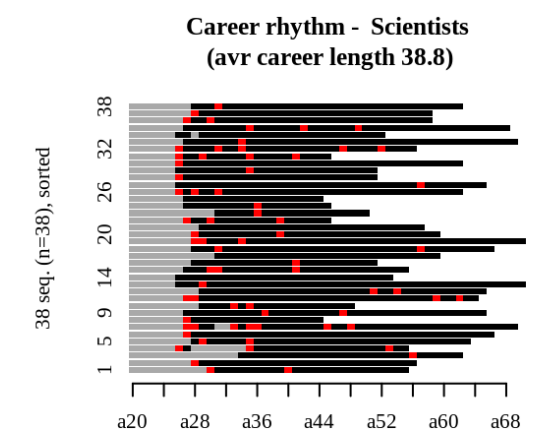




\section{Appendix C: Cluster characteristics}

\begin{tabular}{|c|c|c|c|c|c|c|c|c|c|c|c|c|c|c|c|c|c|c|c|c|c|}
\hline \multirow{3}{*}{ Cluster* } & \multicolumn{9}{|c|}{ Private } & \multicolumn{12}{|c|}{ Public } \\
\hline & & \multirow{2}{*}{\multicolumn{2}{|c|}{$\begin{array}{c}\text { CA } \\
\mathrm{n}=85\end{array}$}} & \multirow{2}{*}{\multicolumn{2}{|c|}{$\begin{array}{c}\text { IC } \\
\mathrm{n}=50\end{array}$}} & \multirow{2}{*}{\multicolumn{2}{|c|}{$\begin{array}{c}\text { LG } \\
\mathrm{n}=29\end{array}$}} & \multirow{2}{*}{\multicolumn{2}{|c|}{$\begin{array}{c}\text { Bankers } \\
\mathrm{n}=48\end{array}$}} & \multirow{2}{*}{\multicolumn{2}{|c|}{$\begin{array}{c}\text { SN } \\
\mathrm{n}=60\end{array}$}} & \multirow{2}{*}{\multicolumn{2}{|c|}{$\begin{array}{c}\text { SC } \\
\mathrm{n}=38\end{array}$}} & \multirow{2}{*}{\multicolumn{2}{|c|}{$\begin{array}{c}\text { Lobbyists } \\
\text { n }=27\end{array}$}} & \multirow{2}{*}{\multicolumn{2}{|c|}{$\begin{array}{c}\text { Unionist } \\
\mathrm{n}=40\end{array}$}} & \multirow{2}{*}{\multicolumn{2}{|c|}{$\begin{array}{c}\text { PP } \\
\mathrm{n}=19\end{array}$}} & \multirow{2}{*}{\multicolumn{2}{|c|}{$\begin{array}{l}\mathbf{E} \& \mathbf{L P} \\
\mathrm{n}=20\end{array}$}} \\
\hline & & & & & & & & & & & & & & & & & & & & & \\
\hline \multirow[t]{2}{*}{ Length of career 20-70 } & 38.14 & $\underline{\underline{35.95}}$ & -3.03 & 38.46 & 0.32 & 39.00 & 0.64 & 40.29 & 2.12 & 39.10 & 1.07 & 38.76 & 0.54 & 35.96 & -1.57 & 39.60 & 1.30 & 35.95 & -1.31 & 38.30 & 0.10 \\
\hline & \multicolumn{21}{|c|}{ ACTIVE SEQUENCE STATES } \\
\hline \multicolumn{22}{|l|}{ Sector } \\
\hline Business & $50.0 \%$ & $90.0 \%$ & 9.26 & $97.0 \%$ & 7.91 & $93.0 \%$ & 5.37 & $80.0 \%$ & 4.93 & $\underline{9.0 \%}$ & -7.67 & $\underline{1.0 \%}$ & -7.13 & $\underline{10.0 \%}$ & -4.88 & $\underline{18.0 \%}$ & -4.88 & $\underline{10.0 \%}$ & -3.99 & $\underline{4.0 \%}$ & -4.79 \\
\hline State administration & $15.0 \%$ & $\underline{2.0 \%}$ & -4.53 & $\underline{0.0 \%}$ & -3.82 & $\underline{2.0 \%}$ & -2.57 & $10.0 \%$ & -1.31 & $73.0 \%$ & 16.53 & $\underline{5.0 \%}$ & -2.20 & $8.0 \%$ & -1.25 & $10.0 \%$ & -1.16 & $7.0 \%$ & -1.26 & $11.0 \%$ & -0.58 \\
\hline Science/Education & $14.0 \%$ & $\underline{6.0 \%}$ & -2.75 & $\underline{2.0 \%}$ & -2.90 & $\underline{1.0 \%}$ & -2.40 & $\underline{2.0 \%}$ & -2.83 & $7.0 \%$ & -1.87 & $93.0 \%$ & 16.85 & $\underline{1.0 \%}$ & -2.19 & $\underline{1.0 \%}$ & -2.89 & $5.0 \%$ & -1.25 & $45.0 \%$ & 4.78 \\
\hline Union & $8.0 \%$ & $\underline{0.0 \%}$ & -3.82 & $\underline{0.0 \%}$ & -2.79 & $1.0 \%$ & -1.77 & $\underline{2.0 \%}$ & -2.04 & $3.0 \%$ & -1.80 & $\underline{0.0 \%}$ & -2.39 & $\underline{0.0 \%}$ & -1.99 & $68.0 \%$ & 17.47 & $4.0 \%$ & -0.89 & $17.0 \%$ & 1.84 \\
\hline Business association & $7.0 \%$ & $\underline{1.0 \%}$ & -2.71 & $\underline{0.0 \%}$ & -2.38 & $2.0 \%$ & -1.39 & $5.0 \%$ & -0.56 & $3.0 \%$ & -1.53 & $\underline{0.0 \%}$ & -2.00 & $77.0 \%$ & 17.43 & $3.0 \%$ & -1.18 & $4.0 \%$ & -0.54 & $0.0 \%$ & -1.50 \\
\hline Politics & $6.0 \%$ & $\underline{1.0 \%}$ & -2.85 & $\underline{1.0 \%}$ & -2.11 & $2.0 \%$ & -1.16 & $\underline{1.0 \%}$ & -2.06 & $4.0 \%$ & -0.61 & $1.0 \%$ & -1.85 & $3.0 \%$ & -0.68 & $1.0 \%$ & -1.72 & $69.0 \%$ & 15.85 & $22.0 \%$ & 4.21 \\
\hline Turbulence & 0.08 & 0.08 & -0.96 & $\underline{0.05}$ & -5.04 & $\underline{0.06}$ & -3.21 & 0.07 & -1.07 & 0.09 & 2.94 & $\underline{0.07}$ & -2.15 & 0.10 & 3.32 & 0.09 & 1.28 & 0.12 & 4.89 & 0.10 & 2.59 \\
\hline \multicolumn{22}{|l|}{ Sub Sector } \\
\hline Industry and Technology & $27.0 \%$ & $25.0 \%$ & -0.59 & $72.0 \%$ & 9.05 & $51.0 \%$ & 3.51 & $\underline{3.0 \%}$ & -4.56 & $\underline{2.0 \%}$ & -5.44 & $23.0 \%$ & -0.66 & $45.0 \%$ & 2.63 & $36.0 \%$ & 1.57 & $\underline{8.0 \%}$ & -2.18 & $\underline{0.0 \%}$ & -3.24 \\
\hline Economy and Finance & $18.0 \%$ & $\underline{5.0 \%}$ & -3.86 & $\underline{1.0 \%}$ & -3.64 & $\underline{5.0 \%}$ & -2.03 & $84.0 \%$ & 14.48 & $13.0 \%$ & -1.24 & $32.0 \%$ & 2.67 & $12.0 \%$ & -0.96 & $8.0 \%$ & -1.85 & $\underline{2.0 \%}$ & -2.08 & $\underline{1.0 \%}$ & -2.29 \\
\hline State administration & $6.0 \%$ & $\underline{1.0 \%}$ & -2.96 & $\underline{1.0 \%}$ & -2.17 & $2.0 \%$ & -1.25 & $\underline{1.0 \%}$ & -2.13 & $3.0 \%$ & -1.41 & $11.0 \%$ & 1.56 & $8.0 \%$ & 0.39 & $8.0 \%$ & 0.69 & $69.0 \%$ & 13.91 & $1.0 \%$ & -1.21 \\
\hline Consultancy and accountancy & $5.0 \%$ & $16.0 \%$ & 7.60 & $7.0 \%$ & 1.18 & $1.0 \%$ & -1.15 & $1.0 \%$ & -1.83 & $1.0 \%$ & -1.74 & $0.0 \%$ & -1.85 & $0.0 \%$ & -1.47 & $0.0 \%$ & -1.90 & $1.0 \%$ & -1.08 & $0.0 \%$ & -1.31 \\
\hline Transportation and infrastructure & $5.0 \%$ & $14.0 \%$ & 5.65 & $4.0 \%$ & -0.39 & $3.0 \%$ & -0.77 & $2.0 \%$ & -1.44 & $5.0 \%$ & 0.02 & $1.0 \%$ & -1.55 & $3.0 \%$ & -0.82 & $3.0 \%$ & -1.02 & $1.0 \%$ & -1.21 & $0.0 \%$ & -1.42 \\
\hline Health & $5.0 \%$ & $3.0 \%$ & -0.63 & $11.0 \%$ & 2.78 & $0.0 \%$ & -1.39 & $5.0 \%$ & 0.21 & $9.0 \%$ & 1.89 & $0.0 \%$ & -1.53 & $0.0 \%$ & -1.29 & $4.0 \%$ & -0.21 & $0.0 \%$ & -1.11 & $5.0 \%$ & 0.13 \\
\hline Agriculture and food production & $5.0 \%$ & $2.0 \%$ & -1.95 & $\underline{0.0 \%}$ & -2.00 & $33.0 \%$ & 7.76 & $\underline{0.0 \%}$ & -2.00 & $3.0 \%$ & -1.13 & $4.0 \%$ & -0.55 & $16.0 \%$ & 2.95 & $7.0 \%$ & 0.49 & $1.0 \%$ & -0.99 & $5.0 \%$ & -0.03 \\
\hline Commerce and Service & $4.0 \%$ & $13.0 \%$ & 6.09 & $2.0 \%$ & -1.21 & $3.0 \%$ & -0.36 & $\underline{0.0 \%}$ & -2.02 & $\underline{1.0 \%}$ & -1.95 & $0.0 \%$ & -1.78 & $2.0 \%$ & -0.58 & $7.0 \%$ & 1.25 & $3.0 \%$ & -0.40 & $0.0 \%$ & -1.26 \\
\hline Law & $4.0 \%$ & $10.0 \%$ & 3.86 & $1.0 \%$ & -1.33 & $0.0 \%$ & -1.19 & $0.0 \%$ & -1.40 & $3.0 \%$ & -0.52 & $10.0 \%$ & 2.20 & $1.0 \%$ & -0.91 & $2.0 \%$ & -0.65 & $0.0 \%$ & -0.95 & $0.0 \%$ & -0.98 \\
\hline Culture and Media & $4.0 \%$ & $9.0 \%$ & 3.30 & $0.0 \%$ & -1.67 & $0.0 \%$ & -1.24 & $0.0 \%$ & -1.48 & $7.0 \%$ & 2.08 & $4.0 \%$ & 0.28 & $1.0 \%$ & -0.93 & $1.0 \%$ & -0.93 & $2.0 \%$ & -0.47 & $0.0 \%$ & -0.98 \\
\hline Local governance & $4.0 \%$ & $\underline{1.0 \%}$ & -2.01 & $0.0 \%$ & -1.78 & $0.0 \%$ & -1.32 & $0.0 \%$ & -1.69 & $3.0 \%$ & -0.04 & $0.0 \%$ & -1.32 & $2.0 \%$ & -0.68 & $14.0 \%$ & 4.70 & $3.0 \%$ & -0.08 & $26.0 \%$ & 6.80 \\
\hline Military and Police & $3.0 \%$ & $1.0 \%$ & -1.47 & $0.0 \%$ & -1.33 & $1.0 \%$ & -0.77 & $0.0 \%$ & -1.23 & $14.0 \%$ & 7.33 & $0.0 \%$ & -1.23 & $0.0 \%$ & -1.02 & $0.0 \%$ & -1.22 & $3.0 \%$ & 0.16 & $2.0 \%$ & -0.13 \\
\hline Educational sector & $3.0 \%$ & $1.0 \%$ & -1.91 & $0.0 \%$ & -1.64 & $0.0 \%$ & -1.22 & $0.0 \%$ & -1.61 & $1.0 \%$ & -1.37 & $0.0 \%$ & -1.24 & $0.0 \%$ & -1.17 & $1.0 \%$ & -0.95 & $5.0 \%$ & 0.52 & $57.0 \%$ & 16.01 \\
\hline Business & $3.0 \%$ & $\underline{0.0 \%}$ & -2.07 & $0.0 \%$ & -1.64 & $0.0 \%$ & -1.23 & $2.0 \%$ & -0.68 & $9.0 \%$ & 4.97 & $1.0 \%$ & -1.16 & $6.0 \%$ & 1.76 & $5.0 \%$ & 1.21 & $2.0 \%$ & -0.41 & $0.0 \%$ & -1.04 \\
\hline Administration & $2.0 \%$ & $\underline{0.0 \%}$ & -2.35 & $0.0 \%$ & -1.61 & $0.0 \%$ & -1.35 & $0.0 \%$ & -1.78 & $5.0 \%$ & 2.82 & $13.0 \%$ & 7.77 & $0.0 \%$ & -1.02 & $1.0 \%$ & -0.73 & $1.0 \%$ & -0.67 & $0.0 \%$ & -1.11 \\
\hline Science/Education & $1.0 \%$ & $0.0 \%$ & -1.32 & $0.0 \%$ & -1.29 & $0.0 \%$ & -0.76 & $0.0 \%$ & -1.12 & $2.0 \%$ & 2.20 & $0.0 \%$ & -1.11 & $3.0 \%$ & 1.84 & $3.0 \%$ & 2.07 & $0.0 \%$ & -0.76 & $2.0 \%$ & 0.67 \\
\hline International organisations & $1.0 \%$ & $0.0 \%$ & -1.39 & $0.0 \%$ & -1.10 & $1.0 \%$ & -0.48 & $1.0 \%$ & -0.34 & $7.0 \%$ & 5.72 & $1.0 \%$ & -0.43 & $0.0 \%$ & -0.62 & $0.0 \%$ & -1.01 & $0.0 \%$ & -0.68 & $0.0 \%$ & -0.70 \\
\hline
\end{tabular}




\begin{tabular}{|c|c|c|c|c|c|c|c|c|c|c|c|c|c|c|c|c|c|c|c|c|c|}
\hline \multirow{4}{*}{$\begin{array}{l}\text { Cluster* } \\
\text { The Royal Court }\end{array}$} & \multicolumn{9}{|c|}{ Private } & \multicolumn{12}{|c|}{ Public } \\
\hline & \multirow{2}{*}{\multicolumn{3}{|c|}{$\begin{array}{c}\text { CA } \\
\mathrm{n}=85\end{array}$}} & \multirow{2}{*}{\multicolumn{2}{|c|}{$\begin{array}{c}\text { IC } \\
\mathrm{n}=50\end{array}$}} & \multirow{2}{*}{\multicolumn{2}{|c|}{$\begin{array}{c}\text { LG } \\
\mathrm{n}=29\end{array}$}} & \multirow{2}{*}{\multicolumn{2}{|c|}{$\begin{array}{c}\text { Bankers } \\
\mathrm{n}=48\end{array}$}} & \multirow{2}{*}{\multicolumn{2}{|c|}{$\begin{array}{c}\mathbf{S N} \\
\mathrm{n}=60\end{array}$}} & \multirow{2}{*}{\multicolumn{2}{|c|}{$\begin{array}{c}\text { sC } \\
\mathrm{n}=38\end{array}$}} & \multirow{2}{*}{\multicolumn{2}{|c|}{$\begin{array}{l}\text { Lobbyists } \\
\qquad n=27\end{array}$}} & \multirow{2}{*}{\multicolumn{2}{|c|}{$\begin{array}{c}\text { Unionist } \\
\mathrm{n}=40\end{array}$}} & \multirow{2}{*}{\multicolumn{2}{|c|}{$\begin{array}{c}\text { PP } \\
\mathrm{n}=19\end{array}$}} & \multirow{2}{*}{\multicolumn{2}{|c|}{$\begin{array}{l}\mathbf{E} \& \mathbf{L P} \\
\mathrm{n}=20\end{array}$}} \\
\hline & & & & & & & & & & & & & & & & & & & & & \\
\hline & $1.0 \%$ & $0.0 \%$ & -1.42 & $0.0 \%$ & -1.04 & $0.0 \%$ & -0.77 & $0.0 \%$ & -1.01 & $9.0 \%$ & 6.83 & $0.0 \%$ & -0.89 & $0.0 \%$ & -0.74 & $0.0 \%$ & -0.92 & $0.0 \%$ & -0.61 & $0.0 \%$ & -0.63 \\
\hline Organisations & $0.0 \%$ & $0.0 \%$ & -0.53 & $0.0 \%$ & -0.88 & $0.0 \%$ & -0.65 & $0.0 \%$ & -0.14 & $2.0 \%$ & 3.22 & $0.0 \%$ & -0.76 & $0.0 \%$ & -0.63 & $0.0 \%$ & -0.78 & $0.0 \%$ & -0.13 & $1.0 \%$ & 0.98 \\
\hline Turbulence & 0.09 & 0.10 & 1.75 & $\underline{0.08}$ & -2.01 & $\underline{0.07}$ & -2.60 & $\underline{0.08}$ & -2.49 & 0.11 & 3.27 & 0.09 & -0.01 & 0.12 & 2.32 & 0.07 & -2.63 & 0.13 & 3.01 & 0.09 & -0.79 \\
\hline \multicolumn{22}{|l|}{ Career level } \\
\hline $1-2$ & $4.0 \%$ & $\underline{1.0 \%}$ & -2.80 & $\underline{0.0 \%}$ & -2.33 & $4.0 \%$ & -0.05 & $\underline{0.0 \%}$ & -2.23 & $2.0 \%$ & -1.22 & $1.0 \%$ & -1.84 & $0.0 \%$ & -1.62 & $23.0 \%$ & 10.77 & $4.0 \%$ & 0.14 & $13.0 \%$ & 3.59 \\
\hline $3-4$ & $33.0 \%$ & $34.0 \%$ & 0.46 & $30.0 \%$ & -0.98 & $\underline{18.0 \%}$ & -4.05 & $35.0 \%$ & 0.61 & $34.0 \%$ & 0.36 & $41.0 \%$ & 2.49 & $44.0 \%$ & 2.92 & $31.0 \%$ & -0.79 & $25.0 \%$ & -1.67 & $33.0 \%$ & -0.03 \\
\hline $5-6$ & $47.0 \%$ & $55.0 \%$ & 3.72 & $41.0 \%$ & -1.85 & $56.0 \%$ & 2.13 & $41.0 \%$ & -1.72 & $46.0 \%$ & -0.48 & $50.0 \%$ & 0.98 & $47.0 \%$ & 0.10 & $\underline{35.0 \%}$ & -3.24 & $42.0 \%$ & -0.87 & $49.0 \%$ & 0.50 \\
\hline $7-8$ & $16.0 \%$ & $\underline{10.0 \%}$ & -2.92 & $28.0 \%$ & 4.20 & $22.0 \%$ & 1.44 & $24.0 \%$ & 2.54 & $18.0 \%$ & 0.87 & $\underline{8.0 \%}$ & -2.35 & $9.0 \%$ & -1.90 & $11.0 \%$ & -1.69 & $28.0 \%$ & 2.41 & $\underline{4.0 \%}$ & -2.49 \\
\hline Turbulence & 0.15 & $\underline{0.14}$ & -2.63 & 0.16 & 2.29 & $\underline{0.12}$ & -3.99 & 0.16 & 1.90 & 0.15 & 0.31 & 0.16 & 1.84 & 0.15 & -0.14 & 0.14 & -1.62 & 0.19 & 4.52 & 0.14 & -1.62 \\
\hline \multicolumn{22}{|l|}{ Organisation Size } \\
\hline Small & $2.0 \%$ & $6.0 \%$ & 3.75 & $1.0 \%$ & -0.79 & $4.0 \%$ & 0.83 & $1.0 \%$ & -0.66 & $2.0 \%$ & -0.43 & $0.0 \%$ & -1.41 & $2.0 \%$ & -0.19 & $0.0 \%$ & -1.17 & $1.0 \%$ & -0.45 & $0.0 \%$ & -1.00 \\
\hline Medium & $16.0 \%$ & $26.0 \%$ & 3.78 & $\underline{3.0 \%}$ & -3.71 & $38.0 \%$ & 4.58 & $\underline{9.0 \%}$ & -2.02 & $\underline{9.0 \%}$ & -2.42 & $\underline{3.0 \%}$ & -3.30 & $12.0 \%$ & -0.80 & $16.0 \%$ & 0.02 & $8.0 \%$ & -1.39 & $55.0 \%$ & 6.75 \\
\hline Large & $38.0 \%$ & $39.0 \%$ & 0.25 & $26.0 \%$ & -2.61 & $13.0 \%$ & -3.93 & $45.0 \%$ & 1.52 & $52.0 \%$ & 3.30 & $52.0 \%$ & 2.49 & $36.0 \%$ & -0.27 & $39.0 \%$ & 0.12 & $27.0 \%$ & -1.37 & $27.0 \%$ & -1.39 \\
\hline Very large & $44.0 \%$ & $\underline{29.0 \%}$ & -4.08 & $70.0 \%$ & 5.44 & $45.0 \%$ & 0.28 & $44.0 \%$ & 0.17 & $38.0 \%$ & -1.34 & $46.0 \%$ & 0.37 & $50.0 \%$ & 0.90 & $45.0 \%$ & 0.21 & $64.0 \%$ & 2.47 & $\underline{18.0 \%}$ & -3.22 \\
\hline Turbulence & 0.11 & 0.12 & 1.88 & $\underline{0.09}$ & -2.84 & 0.09 & -1.64 & 0.11 & -0.24 & 0.12 & 2.95 & 0.09 & -1.84 & 0.11 & 0.61 & 0.11 & -0.28 & 0.12 & 1.00 & 0.10 & -0.55 \\
\hline \multicolumn{22}{|l|}{ Geography } \\
\hline Abroad & $6.0 \%$ & $10.0 \%$ & 2.72 & $10.0 \%$ & 2.19 & $5.0 \%$ & -0.29 & $5.0 \%$ & -0.50 & $9.0 \%$ & 1.35 & $2.0 \%$ & -1.74 & $2.0 \%$ & -1.31 & $\underline{0.0 \%}$ & -2.65 & $5.0 \%$ & -0.21 & $0.0 \%$ & -1.87 \\
\hline Outside the Copenhagen Area & $19.0 \%$ & $\underline{11.0 \%}$ & -2.55 & $\underline{6.0 \%}$ & -2.91 & $83.0 \%$ & 11.17 & $\underline{6.0 \%}$ & -2.88 & $\underline{6.0 \%}$ & -3.28 & $36.0 \%$ & 3.47 & $\underline{2.0 \%}$ & -2.76 & $16.0 \%$ & -0.53 & $14.0 \%$ & -0.60 & $57.0 \%$ & 5.43 \\
\hline Copenhagen Area & $75.0 \%$ & $79.0 \%$ & 1.22 & $83.0 \%$ & 1.80 & $11.0 \%$ & 10.52 & $89.0 \%$ & 2.96 & $85.0 \%$ & 2.53 & $\underline{62.0 \%}$ & -2.53 & $95.0 \%$ & 3.21 & $84.0 \%$ & 1.67 & $80.0 \%$ & 0.67 & $\underline{43.0 \%}$ & -4.35 \\
\hline \multirow[t]{2}{*}{ Turbulence } & 0.09 & 0.10 & 1.13 & 0.11 & 2.91 & 0.09 & 0.20 & 0.08 & -1.56 & 0.09 & 0.31 & 0.09 & -0.92 & 0.08 & -1.17 & $\underline{0.07}$ & -3.43 & 0.12 & 2.49 & 0.09 & -0.10 \\
\hline & \multicolumn{21}{|c|}{ DESCRIPTIVE CHARACTERISTICS } \\
\hline Men & $80.8 \%$ & $76.5 \%$ & -1.13 & $92.0 \%$ & 2.14 & $93.1 \%$ & 1.74 & $89.6 \%$ & 1.64 & $86.7 \%$ & 1.25 & $73.7 \%$ & -1.16 & $70.4 \%$ & -1.42 & $\underline{67.5 \%}$ & -2.24 & $78.9 \%$ & $\begin{array}{c}-0.21 \\
\end{array}$ & $70.0 \%$ & -1.26 \\
\hline Age (in 2015) & 59.2 & $\underline{56.6}$ & -3.12 & 60.1 & 0.88 & 60.7 & 1.04 & 62.9 & 3.22 & 60.3 & 1.15 & 59.1 & -0.06 & 56.3 & -1.84 & 59.8 & 0.53 & 56.2 & -1.58 & 58.4 & -0.41 \\
\hline \multicolumn{22}{|l|}{ Level of education } \\
\hline Ph.D. & $13.2 \%$ & $11.8 \%$ & -0.43 & $10.0 \%$ & -0.71 & $\underline{0.0 \%}$ & -2.17 & $4.2 \%$ & -1.96 & $8.3 \%$ & -1.21 & $81.6 \%$ & 13.05 & $7.4 \%$ & -0.92 & $0.0 \%$ & -2.59 & $0.0 \%$ & -1.74 & $0.0 \%$ & -1.79 \\
\hline Higher Degree & $59.9 \%$ & $65.9 \%$ & 1.26 & $72.0 \%$ & 1.86 & $\underline{31.0 \%}$ & -3.29 & $70.8 \%$ & 1.64 & $81.7 \%$ & 3.72 & $\underline{15.8 \%}$ & -5.81 & $92.6 \%$ & 3.58 & $27.5 \%$ & -4.39 & $73.7 \%$ & 1.25 & $45.0 \%$ & -1.39 \\
\hline First Degree & $13.0 \%$ & $15.3 \%$ & 0.71 & $8.0 \%$ & -1.12 & $44.8 \%$ & 5.27 & $6.2 \%$ & -1.49 & $6.7 \%$ & -1.57 & $2.6 \%$ & -2.00 & $0.0 \%$ & -2.07 & $7.5 \%$ & -1.09 & $21.1 \%$ & 1.07 & $45.0 \%$ & 4.36 \\
\hline Vocational & $11.3 \%$ & $5.9 \%$ & -1.76 & $10.0 \%$ & -0.31 & $20.7 \%$ & 1.66 & $16.7 \%$ & 1.25 & $3.3 \%$ & -2.11 & $0.0 \%$ & -2.31 & $0.0 \%$ & -1.92 & $47.5 \%$ & 7.60 & $5.3 \%$ & -0.84 & $5.0 \%$ & -0.91 \\
\hline
\end{tabular}




\begin{tabular}{|c|c|c|c|c|c|c|c|c|c|c|c|c|c|c|c|c|c|c|c|c|c|}
\hline \multirow{3}{*}{ Cluster* } & \multicolumn{9}{|c|}{ Private } & \multicolumn{12}{|c|}{ Public } \\
\hline & & \multirow{2}{*}{\multicolumn{2}{|c|}{$\begin{array}{c}\text { CA } \\
\mathrm{n}=85\end{array}$}} & \multirow{2}{*}{\multicolumn{2}{|c|}{$\begin{array}{c}\text { IC } \\
\mathrm{n}=50\end{array}$}} & \multirow{2}{*}{\multicolumn{2}{|c|}{$\begin{array}{c}\text { LG } \\
\mathrm{n}=29\end{array}$}} & \multirow{2}{*}{\multicolumn{2}{|c|}{$\begin{array}{c}\text { Bankers } \\
\mathrm{n}=48\end{array}$}} & \multirow{2}{*}{\multicolumn{2}{|c|}{$\begin{array}{c}\text { SN } \\
\mathrm{n}=60\end{array}$}} & \multirow{2}{*}{\multicolumn{2}{|c|}{$\begin{array}{c}\text { SC } \\
\mathrm{n}=38\end{array}$}} & \multirow{2}{*}{\multicolumn{2}{|c|}{$\begin{array}{c}\text { Lobbyists } \\
\text { n }=27\end{array}$}} & \multirow{2}{*}{\multicolumn{2}{|c|}{$\begin{array}{c}\text { Unionist } \\
\mathrm{n}=40\end{array}$}} & \multirow{2}{*}{\multicolumn{2}{|c|}{$\begin{array}{c}\text { PP } \\
\mathrm{n}=19\end{array}$}} & \multirow{2}{*}{\multicolumn{2}{|c|}{$\begin{array}{l}\mathbf{E} \& \mathbf{L P} \\
\mathrm{n}=20\end{array}$}} \\
\hline & & & & & & & & & & & & & & & & & & & & & \\
\hline None & $2.2 \%$ & $1.2 \%$ & -0.70 & $0.0 \%$ & -1.13 & $3.4 \%$ & 0.46 & $0.0 \%$ & -1.10 & $0.0 \%$ & -1.25 & $0.0 \%$ & -0.97 & $0.0 \%$ & -0.80 & $15.0 \%$ & 5.80 & $0.0 \%$ & -0.67 & $5.0 \%$ & 0.87 \\
\hline \multicolumn{22}{|l|}{ Area of education } \\
\hline Business economy & $12.5 \%$ & $30.6 \%$ & 5.65 & $26.0 \%$ & 3.07 & $20.7 \%$ & 1.38 & $6.2 \%$ & -1.40 & $1.7 \%$ & -2.73 & $\underline{2.6 \%}$ & -1.93 & $\underline{0.0 \%}$ & -2.03 & $\underline{0.0 \%}$ & -2.51 & $0.0 \%$ & -1.68 & $10.0 \%$ & -0.35 \\
\hline Engineering \& technical sciences & $12.5 \%$ & $16.5 \%$ & 1.25 & $34.0 \%$ & 4.89 & $27.6 \%$ & 2.55 & $4.2 \%$ & -1.85 & $5.0 \%$ & -1.90 & $13.2 \%$ & 0.14 & $7.4 \%$ & -0.83 & $\underline{2.5 \%}$ & -2.01 & $0.0 \%$ & -1.68 & $0.0 \%$ & -1.73 \\
\hline Agriculture & $1.2 \%$ & $0.0 \%$ & -1.14 & $0.0 \%$ & -0.83 & $13.8 \%$ & 6.45 & $0.0 \%$ & -0.81 & $1.7 \%$ & 0.38 & $0.0 \%$ & -0.71 & $0.0 \%$ & -0.59 & $0.0 \%$ & -0.73 & $0.0 \%$ & -0.49 & $0.0 \%$ & -0.50 \\
\hline Economy & $19.5 \%$ & $12.9 \%$ & -1.72 & $10.0 \%$ & -1.81 & $6.9 \%$ & -1.77 & $50.0 \%$ & 5.66 & $15.0 \%$ & -0.95 & $36.8 \%$ & 2.82 & $25.9 \%$ & 0.87 & $\underline{5.0 \%}$ & -2.43 & $31.6 \%$ & 1.36 & $5.0 \%$ & -1.68 \\
\hline Vocational (white collar) & $6.7 \%$ & $5.9 \%$ & -0.33 & $10.0 \%$ & 0.99 & $13.8 \%$ & 1.58 & $16.7 \%$ & 2.94 & $1.7 \%$ & -1.67 & $0.0 \%$ & -1.73 & $0.0 \%$ & -1.44 & $12.5 \%$ & 1.54 & $0.0 \%$ & -1.19 & $0.0 \%$ & -1.23 \\
\hline Army or police & $2.2 \%$ & $1.2 \%$ & -0.70 & $0.0 \%$ & -1.13 & $0.0 \%$ & -0.84 & $0.0 \%$ & -1.10 & $11.7 \%$ & 5.42 & $0.0 \%$ & -0.97 & $0.0 \%$ & -0.80 & $0.0 \%$ & -1.00 & $5.3 \%$ & 0.94 & $0.0 \%$ & -0.69 \\
\hline Natural sciences & $8.7 \%$ & $5.9 \%$ & -1.03 & $12.0 \%$ & 0.88 & $3.4 \%$ & -1.05 & $4.2 \%$ & -1.17 & $10.0 \%$ & 0.39 & $23.7 \%$ & 3.44 & $11.1 \%$ & 0.46 & $2.5 \%$ & -1.46 & $0.0 \%$ & -1.38 & $15.0 \%$ & 1.02 \\
\hline Political science & $8.9 \%$ & $\underline{2.4 \%}$ & -2.36 & $\underline{0.0 \%}$ & -2.35 & $0.0 \%$ & -1.74 & $4.2 \%$ & -1.21 & $21.7 \%$ & 3.76 & $7.9 \%$ & -0.23 & $29.6 \%$ & 3.90 & $7.5 \%$ & -0.33 & $26.3 \%$ & 2.72 & $5.0 \%$ & -0.63 \\
\hline Vocational (blue collar) & $4.6 \%$ & $\underline{0.0 \%}$ & -2.27 & $0.0 \%$ & -1.65 & $6.9 \%$ & 0.61 & $0.0 \%$ & -1.62 & $1.7 \%$ & -1.16 & $0.0 \%$ & -1.42 & $0.0 \%$ & -1.18 & $35.0 \%$ & 9.64 & $5.3 \%$ & 0.15 & $5.0 \%$ & 0.09 \\
\hline Teaching & $3.4 \%$ & $0.0 \%$ & -1.94 & $0.0 \%$ & -1.41 & $0.0 \%$ & -1.05 & $0.0 \%$ & -1.38 & $1.7 \%$ & -0.78 & $0.0 \%$ & -1.21 & $0.0 \%$ & -1.01 & $5.0 \%$ & 0.59 & $10.5 \%$ & 1.75 & $45.0 \%$ & 10.51 \\
\hline Humanities & $5.0 \%$ & $10.6 \%$ & 2.65 & $2.0 \%$ & -1.04 & $0.0 \%$ & -1.28 & $2.1 \%$ & -0.98 & $5.0 \%$ & 0.00 & $5.3 \%$ & 0.09 & $3.7 \%$ & -0.32 & $0.0 \%$ & -1.52 & $10.5 \%$ & 1.12 & $10.0 \%$ & 1.05 \\
\hline Law & $12.3 \%$ & $12.9 \%$ & 0.19 & $6.0 \%$ & -1.44 & $3.4 \%$ & -1.51 & $10.4 \%$ & -0.43 & $23.3 \%$ & 2.80 & $10.5 \%$ & -0.35 & $22.2 \%$ & 1.62 & $12.5 \%$ & 0.04 & $10.5 \%$ & -0.24 & $0.0 \%$ & -1.71 \\
\hline None & $2.2 \%$ & $1.2 \%$ & -0.70 & $0.0 \%$ & -1.13 & $3.4 \%$ & 0.46 & $0.0 \%$ & -1.10 & $0.0 \%$ & -1.25 & $0.0 \%$ & -0.97 & $0.0 \%$ & -0.80 & $15.0 \%$ & 5.80 & $0.0 \%$ & -0.67 & $5.0 \%$ & 0.87 \\
\hline \multicolumn{22}{|l|}{ Social background } \\
\hline Upper class & $27.9 \%$ & $29.4 \%$ & 0.35 & $44.0 \%$ & 2.70 & $25.0 \%$ & -0.36 & $41.4 \%$ & 2.21 & $31.7 \%$ & 0.71 & $28.9 \%$ & 0.14 & $22.2 \%$ & -0.68 & $\underline{5.0 \%}$ & -3.39 & $15.8 \%$ & -1.20 & $20.0 \%$ & -0.81 \\
\hline Upper middle class & $23.6 \%$ & $29.4 \%$ & 1.41 & $22.0 \%$ & -0.28 & $20.8 \%$ & -0.37 & $\underline{3.4 \%}$ & -3.50 & $28.3 \%$ & 0.93 & $26.3 \%$ & 0.41 & $37.0 \%$ & 1.69 & $\underline{10.0 \%}$ & -2.13 & $36.8 \%$ & 1.39 & $15.0 \%$ & -0.93 \\
\hline Lower middle class & $18.5 \%$ & $14.1 \%$ & -1.17 & $18.0 \%$ & -0.10 & $25.0 \%$ & 0.93 & $27.6 \%$ & 1.72 & $15.0 \%$ & -0.75 & $15.8 \%$ & -0.45 & $18.5 \%$ & 0.00 & $12.5 \%$ & -1.03 & $15.8 \%$ & -0.31 & $40.0 \%$ & 2.53 \\
\hline Farmers & $7.5 \%$ & $7.1 \%$ & -0.16 & $2.0 \%$ & -1.57 & $4.2 \%$ & -0.70 & $3.4 \%$ & -1.15 & $6.7 \%$ & -0.25 & $13.2 \%$ & 1.40 & $14.8 \%$ & 1.49 & $10.0 \%$ & 0.63 & $15.8 \%$ & 1.40 & $5.0 \%$ & -0.43 \\
\hline Working class & $11.8 \%$ & $7.1 \%$ & -1.50 & $8.0 \%$ & -0.89 & $14.6 \%$ & 0.48 & $13.8 \%$ & 0.46 & $10.0 \%$ & -0.47 & $10.5 \%$ & -0.26 & $\underline{0.0 \%}$ & -1.96 & $27.5 \%$ & 3.23 & $15.8 \%$ & 0.55 & $20.0 \%$ & 1.16 \\
\hline Missing & $10.8 \%$ & $12.9 \%$ & 0.70 & $6.0 \%$ & -1.16 & $10.4 \%$ & -0.07 & $10.3 \%$ & -0.12 & $8.3 \%$ & -0.67 & $5.3 \%$ & -1.14 & $7.4 \%$ & -0.59 & $35.0 \%$ & 5.18 & $0.0 \%$ & -1.55 & $0.0 \%$ & -1.59 \\
\hline \multicolumn{22}{|l|}{ Grandparents class } \\
\hline Upper class & $21.6 \%$ & $22.4 \%$ & 0.18 & $24.0 \%$ & 0.43 & $41.4 \%$ & 2.67 & $16.7 \%$ & -0.89 & $30.0 \%$ & 1.70 & $26.3 \%$ & 0.73 & $18.5 \%$ & -0.41 & $\underline{5.0 \%}$ & -2.68 & $5.3 \%$ & -1.77 & $15.0 \%$ & -0.74 \\
\hline Upper middle class & $12.0 \%$ & $10.6 \%$ & -0.45 & $6.0 \%$ & -1.39 & $3.4 \%$ & -1.47 & $20.8 \%$ & 1.99 & $8.3 \%$ & -0.95 & $18.4 \%$ & 1.27 & $18.5 \%$ & 1.07 & $12.5 \%$ & 0.10 & $15.8 \%$ & 0.52 & $10.0 \%$ & -0.28 \\
\hline Lower middle class & $14.4 \%$ & $10.6 \%$ & -1.13 & $20.0 \%$ & 1.20 & $10.3 \%$ & -0.65 & $16.7 \%$ & 0.47 & $18.3 \%$ & 0.93 & $13.2 \%$ & -0.23 & $11.1 \%$ & -0.51 & $10.0 \%$ & -0.84 & $15.8 \%$ & 0.17 & $20.0 \%$ & 0.73 \\
\hline Farmers & $11.3 \%$ & $10.6 \%$ & -0.23 & $14.0 \%$ & 0.64 & $20.7 \%$ & 1.65 & $\underline{2.1 \%}$ & -2.14 & $8.3 \%$ & -0.78 & $10.5 \%$ & -0.16 & $22.2 \%$ & 1.85 & $12.5 \%$ & 0.25 & $10.5 \%$ & -0.11 & $10.0 \%$ & -0.19 \\
\hline Working class & $10.3 \%$ & $11.8 \%$ & 0.48 & $8.0 \%$ & -0.58 & $0.0 \%$ & -1.89 & $14.6 \%$ & 1.03 & $5.0 \%$ & -1.47 & $10.5 \%$ & 0.04 & $0.0 \%$ & -1.82 & $12.5 \%$ & 0.47 & $31.6 \%$ & 3.11 & $20.0 \%$ & 1.45 \\
\hline Missing & $30.3 \%$ & $34.1 \%$ & 0.86 & $28.0 \%$ & -0.38 & $24.1 \%$ & -0.75 & $29.2 \%$ & -0.18 & $30.0 \%$ & -0.05 & $21.1 \%$ & -1.30 & $29.6 \%$ & -0.08 & $47.5 \%$ & 2.49 & $21.1 \%$ & -0.90 & $25.0 \%$ & -0.53 \\
\hline
\end{tabular}




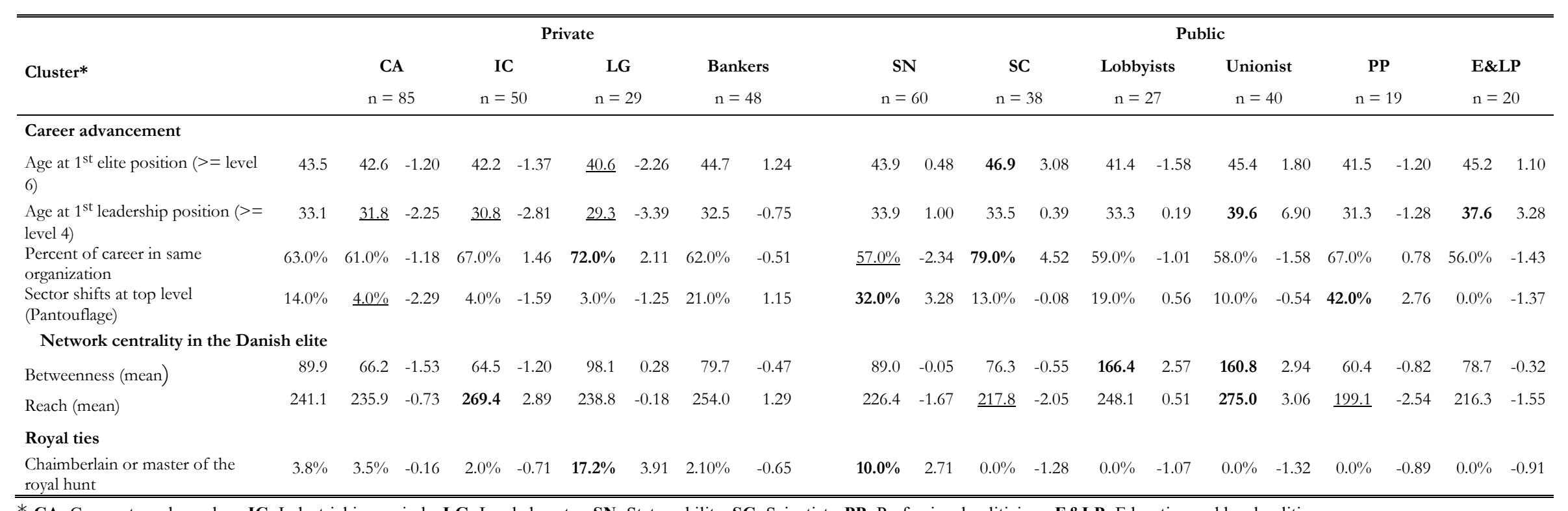

* CA: Corporate ambassadors, IC: Industrial inner circle, LG: Landed gentry, SN: State nobility, SC: Scientists, PP: Professional politicians, E\&LP: Education and local politics.

Underlined cell have significantly lower values than expected, bold significantly higher than expecteted $(\mathrm{p}<0.05)$. 